\title{
California's New Medical Care Law and Program ${ }^{\dagger}$.
}

\section{Jacobus tenBroek*}

"Every county and every city and county shall relieve and support all incompetent, poor, indigent persons and those incapacitated by age, disease, or accident, lawfully resident therein ...."

"[T] he boards of supervisors in each county may provide ... Inedical and dental care and lealth services and supplies to persons in need thereof who are unable to provide the same for themselves, and for these purposes may levy the necessary taxes. Each county inay ... provide the means to meet promptly and adequately the health needs of the indigent sick, the aged, and the poor, for the better prevention of serious illness and incapacity, to the end that such persons will not become public charges at the greater expense of those resources set aside for the public health and welfare."

These sections, currently in the California Welfare and Institutions Code, embody traditional American policy: local responsibility for the care of the poor and medical care as a recognized welfare need. ${ }^{3}$

Notwithstanding, state government support of inedical care programs in Califormia goes back as far as state government. It began in 1850-53 with a whole series of measures instituting a systein of state hospitals, ${ }^{4}$ investing public officials with quarantine and other public health powers, ${ }^{\circ}$ providing a compulsory pre-paid lospitalization plan for immigrants by sea $^{6}$ and programs of direct relief and medical care for overland immigrants. ${ }^{7}$

† For invaluable assistance in the preparation of this article, the author is indebted to his colleagues: Julian Friedman, Assistant Research Public Health Analyst, School of Public Health, University of California; Elizabeth MacLatchie, Chief, Division of Social Security, California State Department of Social Welfare; Carel E. H. Mulder, Chief, Division of Medical Care, California State Department of Social Welfare; George K. Wyman, Director, California State Department of Social Welfare.

* Professor, University of California; member, State Social Welfare Board.

1 CAI. WELF. \& INST. CODE § 2500.

2 CAL. WELF. \& INST. CODE $\$ 200$.

3 See RIESENFeld \& MaXwell, MIOdeRn Soctar Legislation 685-822 (1950); Riesenfeld, The Formative Era of American Public Assistance Law, 43 CALIF. L. REv. 175 (1955) ; Abbotr, Public Assistance 349-51 (ed. 1940).

4 Cal. Stat. 1850 , c. 65 ; Cal. Stat. 1851 , c. 127 , c. 129.

5 Cal. Stat. 1850, c. 64 , c. 66 .

6 Cal. Stat. 1850 , c. 65, § 13; Cal. Stat. 1851, c. 87, §6; c. 127, §§ 18, 19.

7 Cal. Stat. 1852, c. 35. See Fanjehauser, A Finaxciat History of CaItFornia 396-97 (Table IV) (1913); tenBroek, California's Welfare Law-Origins and Development, 45 Carrr. L. REv. 241 (1957). 
In the famous case of County of Sacramento $v$. Chambers ${ }^{8}$ the California District Court of Appeals articulated the state responsibility in most sweeping terms: ${ }^{9}$

It has never been, nor will it ever be, questioned that, among the first or primary duties devolving upon a state is that of providing suitable means and measures for the proper care and treatment, at the public expense, of the indigent sick, having no relatives legally liable for their care, support, and treatment, those who are infirm and helpless from the ravages of advancing years and without means of their own or relatives upon whom the law places responsibility for their care and support, and the insane, likewise situated as to means necessary for their care, support, and safe-keeping .... Nor can it for a moment be doubted that it is the duty of the state to take all necessary steps for the promotion of the health and comfort of its inhabitants and to make such regulations as may be conceived to be essential to the protection of the state and the people thereof, so far as such result may be attained, against the visitations and prevalence of deadly epidemical and endemical diseases, and to take and prosecute such health and sanitary steps and measures as will result in stamping them out, or, by recognized methods of scientific treatment, reducing to the lowest possible minimum the percentage of fatalities following therefrom. These are duties which the state owes to its inhabitants for the ... preservation of their general happiness and welfare; and, as is true of the duty of the state in the matter of taking proper care of the impecunious or indigent who are afflicted witl disease and who have no means for caring for themselves or relatives legally responsible for such care, they are duties which the state may perform in the exercise of its sovereignty, even in the absence of direct constitutional authority therefor - indeed, duties which it may discharge under its inherent power of police.

In 1957, the Legislature of California adopted a new medical care law, re-declaring provision for medical service to public assistance recipients to be "a matter of state-wide concern,"10 and superimposing the new arrangement upon rather than displacing the county obligation. ${ }^{11}$ Now, however, there was a new factor: the federal government which provided the impetus and the base.

In this article, California's new medical law and program will be reviewed.

\section{FederaI Legrslation}

In 1956, Congress reached a major decision concerning public provision of medical care for low income groups. It provided a new grant-in-aid program through which the states might purchase medical care for welfare chents. ${ }^{12}$ In terms of the selection of the groups to be served, the state

833 Cal. App. 142, 164 Pac. 613 (1917).

9 Id. at 147, 164 Pac. at 615 .

10 Cal. Stat. 1957, c. 1068, § 2, CAI. WetF. \& INST. Code § 103.7.

11 Cal. Stat. 1957, c. 1068, CaI. WerF. \& INST. Code $\$ 4503$.

1270 Stat. 846 (1956), 42 U.S.C. $\$ \S 303,603,1203,1353$ (Supp. V, 1958). 
agencies to administer the program, the welfare principles to be applied, the impact of these principles on various other phases of the social security system, the state and federal relationships established and the arrangements to be effected between governniental agencies and the purveyors of healing goods and services-in all these respects the congressional decision was a major one.

Since the 1956 amendment to the Social Security Act in large measure governs the kind of medical care program established pursuant to it, the principal features of that amendment need to be set forth.

The new grant-in-aid plan adopted by Congress was closely tied to the programs of public assistance already in existence under the Social Security Act. Only recipients of aged, blind, disabled and children's assistance were made eligible for goods and services under the new program. ${ }^{13}$ These recipients of federally aided public assistance constituted only a minor fraction of the overall group of medically indigent. Excluded were the poor supported by private welfare, those receiving state and county general relief to which the federal government makes no contribution, other poor persons ineligible for federally aided categorical assistance because they lack residence, citizenship or other technical conditions of eligibility unrelated to their poverty and their need for assistance, recipients of old age and survivors insurance who have no other sources of income, and those who derive their support from wages and other sources whose income is low. Sonie question might be raised, moreover, how far the plan was a good start on the road to medical care of the total group of the needy, how far, that is, the plan would be changed to bring new groups into coverage without a substantial change in conception. The anticipated gradual decline in the numbers of persons eligible for categorical public assistance might well bring about reduction of the coverage of the new medical care provisions. It is evident that this result was not only contemplated by the administration's sponsors of the new medical care program but was espoused by them as desirable; they simultaneously introduced proposals designed to speed up just such a decline. ${ }^{14}$ The process of decline niay well be slowed up by the new program. Persons otherwise not interested in public assistance or not eligible for it because their income is sufficient to meet their other needs covered by public assistance may now apply and be eligible for medical care. For these persons, the medical care feature of public assistance will, in effect, be an independent program. That feature may therefore tend to

1370 Stat. 846 (1956), 42 U.S.C. $\$ \S 303,603,1203,1353$ (Sup. V, 1958).

${ }^{14}$ See Statement of Charles I. Schottland, Commissioner of Social Security, Hearings on Public Assistance Titles of the Social Security Act before the House Committee on Ways and Means on H.R. 9120, H.R. 9091, H.R. 10283, H.R. 10284, 84th Cong., 2d Sess. 3-10 (1956) (hereinafter cited as House Hearings). 
sustain public assistance after Old Age Survivors and Disability Insurance and other economic aid programs have become adequate to meet basic needs, if that day slrould come. At the same time, however, persons not eligible for public assistance because of residence, age, disability or other conditions of eligibility-the whole group of general relief recipients, for example-cannot be made eligible for medical care under the program without a basic shift in the conception of the program.

The argument for integrating the new medical care program with the categorical aids was only incidentally presented before Congress. People are living longer. The average age of old age assistance recipients lias risen to nearly 76 . The incidence of illness increases along with the years. Consequently, old age assistance recipients have an increased need for medical care, and frequently also diminished resources wherewith to secure it. ${ }^{15}$ Blindness is often linked with age. Blind public assistance recipients, therefore, also come within the scope of this argument. Other blind persons, the permanently and totally disabled and incapacitated parents in the Aid to Dependent Children (ADC) program constitute groups for whom the need for public aid is, in large neasure, associated with disabling accident or illness. The need for medical care, therefore, is probably high among public assistance recipients. This, lowever, niay only be another way of stating the proposition that poverty and the need for medical care have an intimate connection. Certainly, in any event, some of the conditions of eligibility for public assistance keep persons off the rolls who have the same reasons for needing medical care as those on them; and still others are thereby kept off the rolls who need medical care for other reasons and have no greater ability to secure it. At the same time, self-care for the aged and self-support and self-care for the disabled and the blind were proposed as additions to the purpose clauses of the categorical aid titles of the Social Security Act. Achieveinent of these objectives depends on maintaining or improving the health and physical well-being of the clients. "Better medical care for recipients," argued Social Security Commissioner Schottland, therefore "is desirable in relation not only to their day-to-day needs for such care but in relation to our intensified efforts to help them achieve self-support."16 The need for day-to-day medical care and for self-care and self-support is not confined to recipients of federally aided public assistance. These are equally the need of the rest of the medically indigent population, a fact that Commissioner Schottland knew as well as anybody else. Apparently practical considerations were governing. The strongly expressed opposition of the American Medical Association and the United States Chamber of

${ }^{15}$ Schottland, House Hearings at 39; statement of J. L. Roney, Director, Bureau of Public Assistance, House Hearings at 10.

${ }^{16}$ Schottland, House Hearings at 7. 
Commerce to the medical care program as presented ${ }^{17}$ doubtless would have been far more unrestrained if the proposal had been to link medical care to the social insurances.

The medical aid plan authorized by the 1956 amendments was a vendorpayment program. The language of the amendment itself-the federal government will match "sums expended . . . as old-age assistance . . . in the form of medical or any other type of remedial care ...."118 - did not make this explicit. However, it was so construed by the federal administrators. ${ }^{10}$ Again, the argument in favor of this arrangement and the considerations which had led to its selection for proposal to Congress were not elaborated before Congress. A precedent had been set in 1950 when Congress first authorized federal participation in medical vendor payments on behalf of public assistance recipients. ${ }^{20}$ Before that time, the categorical aid titles had defined assistance as "money payments" to individuals.

Some of the advantages of a program in which public payments are made direct to the vendors are on the side of administrative efficiency in billing, auditing and making payments, in analyzing costs and estimating expenditures. They are also on the side of administrative control of a process which otherwise would involve dealing with numerous individual clients and often with making payments of relatively large amounts to them. Moreover, since payment is certain and the doctor is not involved in making collections from his individual patients, the plan might reasonably be expected to engender good will and a spirit of cooperation on the part of practitioners of the healing arts and their auxiliaries. Since a plan of medical care to low income groups can succeed only with the willing participation of the medical profession, reducing risks and annoyances to them is probably second in importance only to an adequate fee schedule. On the other hand, there are serious disadvantages to a system of vendor payments. They are to be expressed in terms of the welfare of the recipients. Vendor payments in the field of welfare have a long history. They have been thoroughly tried and all but universally discarded in other areas of welfare goods and services. Is there any difference of principle when the item purchased is health services rather than food, fuel or shelter? With respect to these items, that system was abandoned in favor of cash payments to the client in order to safeguard his freedom and make possible quantity and quality controls on the product received. The state purchasing agency might, indeed, find it harder to maintain quantity and quality

17 House Hearings at 330-32.

1870 Stat. 846 (1956), 42 U.S.C. $\S 303$ (Supp. V, 1958). Similar language is used in the other categorical aid amendments.

19 U.S. Bureau of Public Assistance, Dept. Health, Educ. \& Welfare, State Letter 307.

2064 Stat. 549 (1950), 42 U.S.C. $\$ 306$ (1952). 
controls with respect to health services than with respect to fuel, food and shelter. "The system works out," wrote one critic, "as a subsidy for medical practitioners and others who receive the payments rather than as a practical method of providing health services."21 The sharpness of this criticism must be moderated in view of the changing medical care practices of the rest of the community. Increasingly, salaried people and wage earners are purchasing medical care through third party arrangements which, in effect, are more like vendor payments than like the unrestricted cash grant plan. The uneven incidence of the need for medical care and especially the drastic variations in the amount lead many people to buy care on a pre-paid basis. All such plans are in a sense vendor payment plans. The public assistance recipient would more nearly approach this situation if some way were found for his participation in a pre-paid plan and the amount of the pre-payment were mcluded in his grant to be spent for this purpose at his option. If this cannot be done, the vendor-payment plan leaves him in the position occupied by many others in the community-labor union members, veterans and so on-persons who secure medical care without actually handling the payment therefore.

By the 1958 Amendments to the Social Security Act, the states are permitted to provide medical care services either through vendor payments or through cash grants to the recipients. ${ }^{22}$ The vendor payment requirement of the 1956 amendment is thus removed, effective October 1, 1958.

The grant-in-aid formula of the medical care amendment of 1956 differs significantly from the usual public assistance pattern as it then existed and had existed for twenty years. Federal matching of state medical care expenditures was separated from federal matching of other public assistance expenditures and was placed upon an average rather than an individual basis. According to the medical care formula the federal government would pay one-half of the sum derived from multiplying the total number of aged, blind and disabled public assistance recipients by $\$ 6$ a month. In the case of aid to needy children, the federal government would pay onehalf of $\$ 3$ times the number of recipients. The 1956 amendment expressly included as federally matchable state expenditures for insurance premiums, if the state wished to procure medical care by that method. ${ }^{23}$ Under the medical care amendment the state might thus make payments of any size on behalf of a given recipient and still receive federal matching for the payments. Under the usual formula, state expenditures for public assistance purposes (including im some states an item for medical care in addition to

21 Statement of Edgar Hare, Jr., Director, Dept. of Public Welfare, Delaware, House Hearings, supra note 14, at 201.

22 Social Security Amendments of 1958, 72 Stat. 1047-50.

2370 Stat. 846-48 (1956), 42 U.S.C. $\$ \S 303,603$, 1203, 1353 (Supp. V, 1958). 
food, clothing, shelter and incidentals) were matched by the federal government according to a varying ratio up to a specified maximum for each individual recipient. Before October 1956, this ratio was $4 / 5$ ths of the first $\$ 25$ plus $1 / 2$ of the remainder up to $\$ 55$; between October 1956 and October $1958,4 / 5$ ths of the first $\$ 30$ plus $1 / 2$ of the remainder up to $\$ 60$. Thus, under the ordinary public assistance matching formula, no federal matching money was available for state expenditures to or on behalf of any individual in excess of $\$ 60 .^{24}$

The sponsors of the new medical care amendment argued that federal reimbursement on the basis of payments made to the individual and subject to a fixed maximum in each case did not lend itself well to a medical care program. Proof lay in the fact that the states had not generally provided adequate medical care to public assistance recipients before 1956. The averaging principle would accommodate itself better, the sponsors maintained, to the uneven incidence of the need for medical care among public assistance recipients and to the unpredictable and often high cost of such care in any given case. ${ }^{25}$

Under the 1958 Amendments to the Social Security Act, the separate medical care and cash grant public assistance programs were combined into one program, ${ }^{28}$ the federal matching ceiling was fixed at $\$ 65,{ }^{27}$ the averaging principle for federal matching which had been in effect in the medical care program was applied throughout the new combined program and a variable grant matching formula was instituted based on the relationship of a state's per capita income to the per capita income of the United States. ${ }^{28}$

The 1956 amendment to the federal Social Security Act thus embodied

24 Under the 1956 amendment the federal administrators ruled that federal matching funds were available only for those medical care vendor payments made pursuant to the 1956 amendment. An amendment to the Social Security Act adopted in 1957 (71 Stat. 308 (1957), 42 U.S.C. § 303n (Supp. V, 1958)) gives each state the option of operating under the 1956 provision or of using the formula previously in effect. 70 Stat. 852-54 (1956), 42 U.S.C. $\$ \$ 303,1203,1353$ (Supp. V, 1958). See Bierman, Pooled Funds for Medical Care, Medicat Care Sernes (American Public Welfare Ass'n, 1953).

25 See Schottland, House Hearings, supra note 14, at 34-39; Roney, House Hearings at 10; John W. Tramburg, President, American Public Welfare Ass'n, House Hearings at 165. Cf. Dr. J. S. Snoddy, Welfare Commissioner of Alabama: The matter could and should be handled simply by raising the federal ceiling on individual payments. House Hearings at 312 . Ellen Winston, Public Welfare Commissioner, North Carolina: North Carolina would not be able to supply the necessary funds at the matching ratio in the new formula. A higher percentage should be paid by the federal government in low income states. House Hearings at 320 . See also letter of Proctor N. Carter, Director, Division of Welfare, Missouri, House Hearings at 314.

26 Social Security Amendments of 1958, 72 Stat. 1047-50, 42 U.S.C. $\$ \S 303,603,1203,1353$ (Supp. V, 1958). See also Ops. CAI. ATr'y Gen. 58/178, Sept. 4, 1958.

58/178, Sept. 4, 1958.

27 Social Security Amendments of 1958, 72 Stat. 1047-50.

28 Social Security Amendments of 1958, 72 Stat. 1050, 42 U.S.C. $§ 1301$. 
these major features: (1) It authorized federal grants to the states to provide medical care and other remedial services to the recipients of federally aided public assistance programs, a selected minority of the medically indigent. (2) Since medical care was tied to public assistance, state public assistance agencies rather than state liealth agencies were made responsible for admimistration or supervision of administration. (3) Despite this fact and despite the lesson in welfare experience which gave rise to the principle of "cash payment direct to the recipient," the federal administrators interpreted the amendment as providing for a vendor payment program, though the amendment itself did not say this. (4) The matching formula, incorporating as it did an averaging principle, introduced into the public assistance program elements of a system of group aid, to that extent marking a federal departure from the principle of individual need individually determined.

In this manner and by these provisions, the 1956 amendment to the federal Social Security Act and the implementive interpretations of the federal administrators provided the basic framework for a nation-wide program of tax-supported medical care. While the basic framework was sufficiently defined to reveal the general character of the whole structure and while it miglit be anticipated that the federal social security officials, following the pattern in the other public assistance programs, would eventually evolve nore and more detailed regulations, the states were left free to make, and indeed were faced with the necessity of making, a good many decisions of their own on highly important elements of the program.

The federal act limited eligibility for medical care to those eligible for categorical aid. The states had to decide whether all groups of categorical aid recipients should be included in the medical care program and if not all then which ones-the aged, disabled, blind, children; whether groups of non-federally aided public assistance recipients should be included at state expense; whether public assistance recipients with some outside income of their own slrould be included and if so, their precise relationship to the program.

The federal act placed administration in the hands of the state public assistance agency. This left to be worked out: relationships between the public assistance agency and public liealth agencies; the degree of administrative and financial responsibility of the county welfare departments; the character of fiscal arrangements and procedures, especially whether to set up a pooled fund or other sucli device; and, particularly in California, the extent to which the traditional pattern could and should be followed of detailed statutory specification of rights and responsibilities as against delegated discretion to the state administrative agency.

The federal administrative rulings prescribed a vendor-payment pro- 
gram. ${ }^{23}$ This meant only that payments must be made on behalf of recipients to the suppliers of health and remedial services and goods. What suppliers? What services? What goods? Should the payments be to individual practitioners and if so, on a fee or a salary basis? Should practitioners be chosen freely by the recipient or with restrictions? Should the state buy pre-paid insurance, say with Blue Cross or Blue Shield? Should the state contract for the services with county medical societies and other professional organizations? Should medical care payments be made for diagnostic services to all, a part, or none of the caseload, preventive or public liealth services, treatment and surgery, and rehabilitation services? Should a few be fully served or the many served less well? Should treatment be given for some diseases and not others? Should the attempt be to cover all health needs and suppliers: physicians, hospitals, nursing lromes, drugs, dentists, nurses, appliances, diets? If so, drastic limitations would have to be placed on all items unless the state were prepared to provide a great deal of unmatched money. Contrariwise, should only certain items be met but they to a greater extent? If so, which items and to what extent?

These and a host of other equally baffling questions had to be answered and choices made by the states, some by the legislatures and some by administrators.

\section{The California Medical Care Act}

In California the response to the 1956 amendment was immediate, favorable and vigorous. Governor Goodwin Knight, identifying the need among "our senior citizens" for medical care and health services "as their foremost necessity of the day, and the nost important one of this hour," recommended to the Legislature that it authorize state participation in the program and appropriate matching funds from state revenues. ${ }^{30}$ The staff of the State Department of Social Welfare prepared a bill which was introduced by 48 Assemblymen. ${ }^{31}$ In the course of its passage through the Legislature, the bill was amended several times but only in minor particulars. At no time was there any opposition to the proposal. No one appeared against it at any one of the various committee hearings. No one spoke against it on the floor of either house. Unlike their national counterparts, with respect to the 1956 Congressional amendnient, the California Medical Association and the California Chamber of Commerce did not appear in opposition. Indeed, Dr. Dan Kilroy, legislative representative of the California Medical Association, attended all committee meetings

29 Note 19 supra.

${ }^{30}$ Address by Gov. G. Knight, Welfare Council of Metropolitan Los Angeles, Dec. 7, 1956; Message to the California Legislature, Jan. 7, 1957.

31 A.B. 679 (1957). 
at which the bill was considered and stated that the California Medical Association was not opposed to passage of the bill. Dr. Kilroy's support of the bill was consistent with the action of the California Medical Association Council at its meeting on April 27, 1957, when it was agreed to support the program provided (1) emphasis be placed on home and office visits, (2) a fee schedule be devised and, (3) California Physicians' Service be the fiscal agent. The bill was passed unanimously by both houses of the Legislature and signed by the Governor. ${ }^{32}$

In the statute as passed, the Legislature gave few answers to the questions posed above and made few of the choices. The statute is short, contains almost no detailed provisions of any kind and is barren of policy directives. Primarily, it authorizes participation in the federal program, appropriates the matching funds, establishes a medical care premium deposit fund in the state treasury, ${ }^{33}$ allocates administrative authority and fulfills the conditions required to obtain federal funds.

The Governor is authorized to make and execute "all necessary agreements in connection with this chapter as may be required by the United States Government." 34

Accepting the federal ruling that the 1956 Congressional amendment not only provided for a medical care vendor-payment program but made that program exclusive of federal matching of any other state medical care vendor payments, earher state statutes authorizing medical care vendor payments were repealed. ${ }^{35}$ These statutes had been enacted in 1955 pursuant to the federal amendment of $1950 .^{36}$ They directed that part of the aid otherwise payable to the individual should be paid to the public medical institution supplying him with medical or other remedial care, the remainder of the aid to be paid the individual to meet his personal and incidental expenses. As a result of the repealer, part of the aid payment can not be made to the institution. Public assistance recipients in public medical institutions, however, now will continue to receive their aid payments and the grant will be so computed that they may be enabled to pay the institution for board, room, and other services incidental to the medical, surgical and nursing services received. ${ }^{37}$

The persons rendered eligible for medical services and other remedial care are specified. They are recipients of Old Age Security, Aid to Needy Blind, Aid to Partially Self-Supporting Blind, Aid to Needy Children, and "each needy parent or needy person who takes the place of a parent in

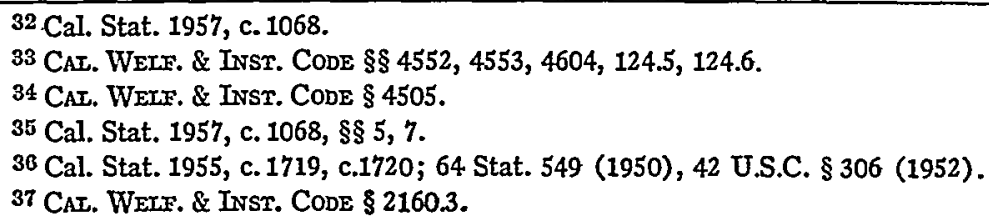


the supervision or care of needy children." eligible for inclusion in the family budget unit under the Aid to Needy Children program but not for a direct ANC grant. ${ }^{39}$ In the statute, therefore, they are not called "recipients," as the other groups are, but are identified in other terms in order to insure their eligibility for fund-covered medical care. By administrative interpretation, "recipients" of ANC covers all children in the family budget unit, including those who by reason of age or other factor are ineligible for an ANC grant. The effect in the ANC prograin of including ineligible children in the family budget unit is that the needs of the inehigible children who are living in the family groupand whose needs therefore are integrated into the needs of the family group-are taken into consideration in determining the needs of the eligible children. The amount of aid granted the eligible children may be increased as a result and the needs of the ineligible children, absorbed in the needs of the family group, may, as a result, also be met to some extent. The regulation directing the inclusion of ineligible children in the family budget unit $^{40}$ had only recently withstood a strong attack by one of the administering counties in the courts. ${ }^{41}$ No payments are made into the medical care fund by the state for ineligible children included in the family budget umit. Notwithstanding, the federal officials, after entertaining preliminary doubts, finally agreed to permit payments out of the fund on behalf of such persons. Thus, by administrative action in the case of needy children living in an ANC family but themselves ineligible for aid, a group of persons has been defined, with the concurrence of the federal officials, "recipients" of ANC for the purpose of determining their eligibility for medical care though they are only indirectly, albeit nevertheless certainly, beneficiaries under the ANC program and though no state money and hence also no federal money is put into the Medical Care Fund to cover their cases.

38 CaL. WeLT. \& INST. CODE $\$ 4552$.

30 Cat. Welf. \& Inst. Code $\$ \$ 1501.5,1511$; State Dept. of Soctat Welfare, Am to Needy ChIndren Manual \& C-201.10. CaI. Welf. \& INST. Code $\$ 1501.5$ says: "During such times as the Federal Government provides funds for the care of a needy relative with whom a needy child or needy children are living, aid to the child or children for any month includes aid to meet the needs of such relative ...."

40 State Dept. of Soctar Welfare, am to Needy Chmdren Manual § C-503 (1956), now incorporated in AD to NeEDY CEMDREN MANuAL \$ C-201.10 (the State Dept. of Social Welfare is hereinafter cited as SDSW).

41 Merced County v. Department of Social Welfare, 148 Cal. App. 2d 540, 307 P.2d 46 (1957), hearing den., Cal. Sup. Ct. Apr. 17, 1957. The court sustained the regulation on the ground that "the rule does not give direct aid to any person except a needy child" eligible for aid under the program. Id. at 542, 307 P.2d at 47. In 1957 the Legislature amended the Welfare \& Institutions Code, placing the validity of the regulation beyond doubt. CAI. WEIF. \& InsT. CODE § 1511 now provides: "For each needy family which includes one or more needy children qualified for aid under this chapter . . . there shall be paid the sums specified ... or so much thereof as is necessary for the adequate care of the needy family ...." (Emphasis added.) 
With respect to two other groups momentarily not recipients, the federal officials ruled differently, at least in part. Persons not receiving aid solely for the reason that aid is withheld to adjust for a previous overpayment and persons whose aid is suspended solely to determine the amount of aid they should be granted, were administratively held entitled to medical care. ${ }^{42}$ The federal officials agreed that these so-called "zero-grant cases" might be held eligible for fund-covered nedical care but insisted that the state make payments into the fund to cover them. As of January 1, 1958, the state changed its regulations to do so. ${ }^{43}$

The exclusion of one group from the medical care program and the inclusion of four others are striking. Recipients of Aid to the Permanently and Totally Disabled were counted out. This was due at least in part and perhaps altogether to the fact that the Permanently and Totally Disabled Program was itself concurrently enacted by the Legislature at the 1957 session. ${ }^{44}$ Recipients of the Aid to Partially Self-Supporting Blind, of Aid to Needy Children in Boarding Homes and Institutions, of ANC in the so-called mismanagement cases in which aid is paid in kind, and aged and blind recipients who are patients in institutions for the mentally ill, were included. ${ }^{45}$ These four groups do not receive federally aided public assistance. The first are ineligible for federal funds because the income and property conditions of eligibility for the program are too generous; ${ }^{46}$ the second, because the children involved are not being cared for in their own homes and by relatives of a specified degree of closeness; ${ }^{47}$ the third, because assistance is not in the form of an unrestricted money payment; 48 the fourth, because of a specific exclusionary provision in the federal Social Security Act. ${ }^{49}$ The public assistance payments niade to these blind persons, children, and recipients in mental institutions, consequently, are derived entirely from state and county sources. Under the new California medical care statute, the state carries the full burden of payments into the Medical Care Premium Deposit Fund for them. ${ }^{50}$

\footnotetext{
42 SDSW Medicax Care Manual \& MC-020.

43 SDSW Fiscas Manual § F-1020.

44 Cal. Stat. 1957, c. 2411, CAL. WELF. \& INST. Code \$§ 4000-4192.

45 CAL. WELF. \& INST. CODE $\S 4552$ (c).

4649 Stat. 645 (1935), as amended, 42 U.S.C. $\S 1202$ (a) (8) (1952).

4749 Stat. 627 (1935), as amended, 42 U.S.C. $\$ 601$ (Supp. V, 1958).

4849 Stat. 628 (1935), as amended, 42 U.S.C. $\$ 603$ (Supp. V, 1958).

4949 Stat. 622, 646 (1935), as amended, 42 U.S.C. $\$ \$ 306,1206$ (1952).

50 The federal officials approved this arrangement despite their contradictory rulings with respect to programs in Pennsylvania and Missouri. Each of those states has had two programs of aid to the blind: one receiving federal funds and for which recipients are eligible in conformity with federal rules and regulations; the other entirely state-supported making grants to blind persons ineligible under the federal rules. The federal officials have long held that the existence of the wholly state-supported program rendered the federally shared prograns out of conformity with federal requirements except for a special statutory provision enacted and twice
} 
Only one other provision of the state statute deals with eligibility. Public assistance recipients are declared ineligible for medical care if they have income in addition to their aid grant with which they may independently purchase care. ${ }^{51}$ This settles one part of the question of the relationship between the medical care program and "special needs" grants and allowances for medical care. ${ }^{\mathbf{2}}$

The California medical care law assigns direct admimistration to the agencies responsible for direct administration of the public assistance program, that is, the county boards of supervisors and welfare departments. ${ }^{53}$ Authorization of the board of supervisors awarding public assistance is made authorization for medical care. ${ }^{54}$ Laws providing for the support of the poor ${ }^{55}$ remain intact. The nedical care statute is to be "construed as an additional method of providing medical services or remedial care to recipients of public assistance." ${ }^{\prime 66}$ The counties put up fifty per cent of the costs of administration; the state fifty per cent of the costs of the liealth goods and services. The federal government puts up the other fifty per cent in both cases. ${ }^{67}$ The State Department of Social Welfare is designated as "the single state agency with full power to supervise every phase of the administration of that program." ${ }^{168}$ The State Social Welfare Board is given sweeping power to "prescribe the policies and scope of the services to be provided ...." The state department is

extended by congress specifically for the purpose of allowing the dual programs in these two states. (Section 344 of the Social Security Act Amendment of 1950, 64 Stat. 554, 42 U.S.C. $\$ 1202 \mathrm{a}$ (1952) extended by $\$ 302$ of the Social Security Act Amendments of 1954, 68 Stat. 1097, 42 U.S.C. \$1202a (Supp. V, 1958), and further extended by Pub. L. No. 85-26 approved Apr. 25, 1957, making the termination date June 30, 1959, 71 Stat. 27, 42 U.S.C. $\$ 1202 a$ (Supp. $V$, 1958). Separate accounting for the non-federal children's and partially self-supporting blind cases has been established at federal insistence in order to make certain that withdrawals from the fund for these groups are not disproportionate. Separate accounting was not required for the old age and blind recipients in mental institutions since they constitute such a very small proportion of the aged and blind caseloads.

51 CAL. WELF. \& INST. CODE $\$ 4576$.

52 SDSW Old Age Securtty Mandal \$§ A-206.1 through A-206.94, ATd to the Bland

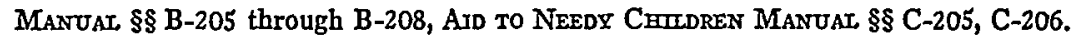

53 CAL. WeLF. \& INST. CODE $\$ 4550$.

54 CAL. WELF. \& INST. CODE $\$ 4551$.

55. CAL. WELF. \& INST. CODE \$§ 200-18.

56 CAL. WeLT. \& INST. CODE $\$ 4503$.

57 CAL. WELF. \& INST. CODE $\$ \S 4552,4602,4603$.

58 CAL. WeTf. \& INST. CODE $\$ 103.7$.

59 Cax. WeLF. \& INST. Code \$ 4555. The Legislature directed the Board (CAx. Wexf. \& Inst. CODE $\S 4557$ ) to appoint a Medical Care Advisory Committee to be representative of "organizations and groups which have had a wide range of experience in providimg medical care" and to give advice "as to the medical needs of public assistance recipients." The Board has appointed three private physicians, one osteopath, one lay person representing a voluntary health agency, one dentist, one lay administrator of a public hospital, one local health officer, and one pharmacist. Notably absent from the list of appointees and from the intention of the Legislature, is any representation of the consumers. 
specifically authorized to contract with public or private agencies, nonprofit membership corporations, medical societies or other medical groups, vendors of medical supplies, private insurance companies and nomprofit hospital service plans. ${ }^{80}$

With qualifications, the State Department of Social Welfare is directed to afford recipients "free choice of arrangements under which they shall receive medical care," and again with qualifications "at least one arrangement available to all recipients of public assistance shall afford free choice among physicians willing to provide services under the terms of a contract entered into pursuant to this section." The qualifications are practicality, and efficient and economical administration. ${ }^{61}$ Discrimination is forbidden against any individual who "in good faith adheres to the teachings of any bona fide church, sect, denomination, or organization and in accordance with its principles depends for healing entirely upon prayer or spiritual means ...."

Medical care is defined by the act in most comprehensive terms. It "may" include "diagnostic, preventive, corrective, and curative services and supplies essential thereto, provided by qualified medical and related personnel for conditions that cause suffering, endanger life, result in illness or infirmity, interfere with capacity for normal activity including employment, or for conditions which may develop into some significant handicap." "Other remedial care" and "treatment by prayer or healing by spiritual means im the practice of the rehgion of any church or religious denomination" are expressly imcluded withm the definition of "medical care." Board, room and personal expenses incidental to hospital care are expressly excluded. ${ }^{\text {e3 }}$

As can be seen from the foregoing summary of the act, the state legislative contribution to the development of the vendor payment medical care program for public assistance recipients was primarily administrative. It supphied the basic and indispensable legal authorization. It fulfilled the conditions and provided the meclianics for securing the federal grant. It distributed administrative authority and responsibility within the state. It set up the pooled fund as the principal fiscal and administrative device. It enumerated the classes of public assistance recipients eligible for medical care. As to the policies to be pursued, the rights and interests to be protected, the scope and character of the care, goods and services to be provided-as to all these the statute is virtually silent. Nor could it have been otherwise considering the relative dearth of medical and actuarial

\footnotetext{
${ }^{80}$ Cat. WetF. \& INST. CODE $\$ 4554$.

B1 CAT. WeIF. \& INST. CODE $\$ 4554$ (b).

62 CAT. WEIF. \& INST. CODE $\$ 4556$.

03 CAT. WeIF. \& Inst. CODE $\$ 4502$.
} 
information, the lack of experience with such programs in the state and the absence of well-matured plans which could have been presented to the legislature for embodiment in the statute.

\section{AdMINISTRATIVE IMPLEMENTATION-GENERAL APPROACH}

The next stage of program development-administrative implementation-was thus beset with a complex of legal, administrative, medical and welfare problems left unresolved by the Legislature. What goods and services should be provided and, within the limits specified by the Legislature, to whom and to what extent? How could expenditures from the fund be continually assessed and adequately controlled? Should vendors be dealt with by group contract or on an individual basis and in either event how should fees be set? How could satisfactory relationships be established and maintained with the relevant professions. How should "special needs" grants and allowances for medical care be meshed with medical care payments out of the fund within the limits of the policy laid down by the Legislature that recipients with sufficient money of their own are not to benefit from the fund. Supplying and implementing solutions to these problems fell to the lot of the staff of the State Department of Social Welfare and the State Social Welfare Board, the latter having been assigned the function of prescribing "the policies and scope of the services" to be rendered as well as the general rule-making authority. ${ }^{04}$

In planning a program of medical care for public assistance recipients, one may accept as true what writers in the field say about such programs. They should be comprehensive. They should promote positive health, detect incipient disease, diagnose and treat existing cases, provide convalscent and rehabilitative services. They should not be confined to one of these phases, or to a specific disease, or give the patient less than continuous care. They should cover physicians' services, including those of general practitioners and specialists, dental services, nursing services, hospitalizations, including convalescent homes, nursing homes and hospitals for the chronically ill, medical social services, laboratory services, drugs and apphances, and custodial care in institutions. ${ }^{65}$ "Money for hospital care and not for home and office calls," argued the National Conference on Care of the Long-Term Patient in 1956, "may result in an unnecessary overcrowding of hospitals. Money for doctors' services and not for the services of physical therapists, nutritionists, medical social workers, and

64 Cat. Welf. \& Inst. Code $\$ 4555$.

65 F. Goldmann, Public Medical Care: Pranciples and Problemss (1945); Greenfield, Medical Care for Welfare Recipients-Basic Problems, (Bureau of Public Admin. 1957); Greenfield, Medical Care for Welfare Recipients-State Programs, (Bureau of Public Admin. 1957); Tax-Supported Personal Health Services for the Needy, A Statement of Principles, 45 Axx. J. OF PUB. HeAtTH 1593 (1955). 
allied professional workers may result in prolonging the period of incapacity, and therefore the need for care. If money is available for certain age groups and not for others, care may be delayed or ended prematurely. Arbitrary limitation on length of care and on amounts of money to be allowed for a particular patient, e.g., so many days lospitalization or money maximums, may make it impossible to carry through the recommendations of physicians and other professional practitioners responsible for care. If funds can be used for certain types of illnesses and not others, e.g., heart conditions, cancer, diabetes, emergency care, etc., the total (or even the most pressing) needs of a patient may not be adequately met."

Viewed administratively and at least in the short range, however, the limitation on available funds also is a truth that has to be accepted. Indeed, the unitary and comprehensive concept of medical care adds greatly to the difficulty in determining how to spend funds, the limitations on which make necessary the exclusion of many medical goods and services.

The federal medical care grant-in-aid formula does not stand in the way of a state adding more funds of its own after the matchable maximum has been reached. The California Legislature decided to match the federal grant on an even basis. This produced in the medical care pool roughly $\$ 29,000,000$, a sum certainly not sufficient to meet all of the medical needs of from 450,000 to 500,000 public assistance recipients. Just what sum would be sufficient for that purpose cannot be known until more data are available as to the kinds and incidence of disease among public assistance recipients, the utilization rate of services, drugs, prostheses and the like and the cost at which these can be purchased.

In view of these unknowns and of the certain inadequacy of the $\$ 29,000,000$ fund, medical care imsurance was quickly eliminated as a possible method of handling the problem. Medical societies and other professional groups also manifested little interest in handling the case load or any major part of it, statewide on a comprehensive prepayment plan basis. No society, group or insurance company responded to the California State Social Welfare Department's invitation to come up with proposals. The Kaiser Health Foundation did, at one time, toy with the idea of offering a pilot project, in Contra Costa County. The plan was not pursued past the stage of informal discussion because of complication in providing home visits and dental care. Reliance on county physicians or panels of physicians was thought to be precluded by the statutory provision about free choice of physicians and by expected opposition alike from recipients and the medical profession. The plan adopted was to purchase goods and services from vendors within a system of an established list of goods and services, nraximum fees and prices and administrative controls on quantity

${ }^{66}$ Chronic Illness in the United States, 2 Comanssion on Crronsc IrLNess 404 (1956). 
and quality. The vendors include private practitioners, group practices, public clinics or voluntary clinics. Within this framework no recipient is to be denied free choice of practitioner under the terms of the rules and regulations. ${ }^{67}$

Two rather elementary principles were followed in determining the goods and services to be rendered. The medical care fund was to be treated as an additional resource wherewith to meet the medical needs of public assistance recipients, not as a substitute or a subsidy for currently available resources, public or private. The needs most common to the greatest number should be served; high cost items sapping the fund for the benefit of a small number should be eliminated. ${ }^{68}$ Easily acceptable as both of these principles would seem, yet as specific applications were worked out their guiding force often was either not perceived or was drawn in question.

In the application of these principles, exclusion from the coverage of the medical care fund by specific illness or disease ${ }^{60}$ by the procedure or mode of treatment ${ }^{70}$ by a group of practitioners, ${ }^{71}$ by the relationship of one group of practitioners to another or by making the services of one group dependent upon another ${ }^{72}$ by the place of rendering the services, ${ }^{73}$ by the kind, cost or quantity of drugs, medicines and devices ${ }^{74}$-all these methods of selecting goods and services for exclusion from the coverage of the fund raise acute and often imponderable and baffling questions as to costs and numbers of recipients and as to the availability of resources in terms of the actual existence of facilities, the adequacy of an existing facility or of one method of treatment as against another, the qualifications

${ }^{67}$ SDSW Medical Care Mandar § MC-022, Otd Age Securtty Manual § A-205.20, Ard

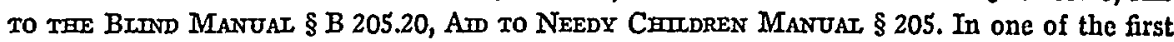
appeal cases reaching the State Social Welfare Board under the new medical care program, the Board held that there was no violation of a recipient's free choice of practitioners where a recipient under the program had been treated by four doctors in a period of several months and the county welfare department refused additional medical authorizations for other physicians until the appellant completed the course of treatment already planned for her by the physician who had been most recently attending. State Social Welfare Board (hereinafter cited as SSWB), Agenda, case No. 40, Mar. 1958. In another case, the appellant contended that she was being denied free choice of physicians by virtue of the fact that few of the physicians in the county were willing to participate in the program. The Board held that it could provide no solution to the problem "in view of the unwillingness of the physicians of the appellant's choice to cooperate in the Medical Care program ...." Free choice of practitioner applies only as among practitioners providing services under the program. SSWB, Agenda, case No. 42, August, 1958.

68 SDSW Medical Care Manual $\$ \$$ MC-012, MC-021, MC-031.1.

69 Id. § MC-040.

70 Id. §§ MC-031.1, MC-031.2.

71 Id. § MC-014.

72 Id. § MC-031.2-Chiropodists before Sept. 1957.

73 Id. §§ MC-031.1, MC-031.2, MC-040.

74 Id. §§ MC-031.2, MC-031.1, MC-046, HANDBO0K, § MC-040.05. 
of various professional groups and the health value of their services. At what point, if any, and by what measure, should care to a given individual, once started, be terminated because of the needs of the whole group and the limitations of the fund? To what extent is it "practical, efficient or economical" - the words of the statute - to provide for free choice of practitioners by the patient or to allow the principle of free choice to enter as a consideration in determining exclusions from the fund? Should the new program be so established as to allow or cause a diversion of patronage from already existing public clinics and other public facilities, whether "administratively inefficient and aesthetically unattractive" or not? ${ }^{76}$ Should the new program serve as a subvention to local costs? How could a policy be avoided which in effect would reward improvident local governments and penalize those which had taken seriously their responsibility for health improvement? Difficult or easy, doubtful or certain, with whatever knowledge and by whatever means, these problems-many of them with philosophical and social implications and histories as old as public health and public welfare-had to be resolved. There was only so much money in the fund.

\section{Administrative Implementation-Program Coverage}

The greatest unmet need of public assistance recipients for medical and other remedial care appeared to be that for home and office visits of physicians and other practitioners and for drugs. Because of the costliness of the service, the fact that the need for it is not so widely distributed among the recipients, and its current availability through county hospitals in many counties, hospitalization was ruled out. Thus a major division was made between in-patient and out-patient care, the former being eliminated from the medical care program altogether. ${ }^{76}$

Included within the services covered by the fund are laboratory services connected with office visits such as blood counts and urinalyses, $\mathrm{X}$-ray and radiological services, and office surgery. ${ }^{77}$

In the interests of early detection of diseases which may run a lengthy as well as a costly course, limited diagnostic appraisal services were included. $^{78}$ These were intended mainly to reacli new public assistance recipients on intake but may also be used to cleck recipients already on

75 Mulder, A Worthwhile Headache-Medical Care, 31 WeLF. NEws 3 (1957).

${ }^{76} \mathrm{~A}$ good deal of difficulty was experienced in drawing the line between inpatient and outpatient services. Diagnostic, laboratory and X-ray services performed in a hospital as a result of a physician's office service rather than in connection with a patient in a hospital or being admitted to a hospital were held to be outpatient services and covered by the fund. SDSW medical Care Manuat § MC-040.

${ }^{77}$ Id. §§ MC-031.1, MC-031.2.

78 Id. \& MC-031.2. 
the rolls. Such diagnostic appraisal, in addition to disclosing hitherto undiagnosed treatable illnesses, gives the local welfare department valuable knowledge in assessing the overall needs of recipients. At the other end of the process of medical diagnosis and treatment, recognition was given the importance of rehabilitation services including them within the coverage of the fund when given within rehabilitation centers meeting the standards of the Bureau of Vocational Rehabilitation. ${ }^{79}$

Going beyond the major line drawn between in-patient and out-patient care, and the elimination of all in-patient care from coverage by the fund, the size of the fund and the anticipated need for goods and services made it necessary to impose limitations on the goods and services provided outpatients. Prosthetic devices such as eye glasses, hearing aids, dentures and the like, despite the very wide-spread need for them among public assistance recipients, were withdrawn from the aegis of the fund. ${ }^{80}$ As a result optometrists were withdrawn from the list of payable practitioners. ${ }^{81}$ Dental care was held to that necessary "for the rehef of pain, or the elimination of acute infection"82 or, in the case of children from 5 to 12 years old, tooth loss. ${ }^{83}$ Altogether omitted were radium and X-ray therapy and diagnosis or treatment given in the absence of the recipient, as by telephone. ${ }^{84}$ Finally, there were four exclusions determined by the character of the illness. No payments are made for treatment of maternity cases, or cases of tuberculosis, venereal disease or mental illness. ${ }^{85}$ These deletions from the coverage of the fund were more difficult and doubtful than any others. Tuberculosis and venereal disease are among those infectious diseases which have been the subjects of special public concern for many years. Activities to control and eradicate them have been conducted by local health agencies in collaboration with state government. ${ }^{80}$ These diseases were therefore excluded from treatment under the medical care fund on the theory that there are available existing facilities reasonably adequate and specifically designed to combat them and to care for

79 Medical Care Manual \& MC-031.2.

80 SDSW MEdicat Care HaNdBook § MC-040.05.

81 Id. \& MC-014.

82 SDSW Medical Care Manuat \& MC-031.1.

83 Id. \& MC-031.2. At this writing, it seems likely that this rule will be changed. The Medical Care Advisory Committee has recommended to the State Social Welfare Board that complete dental care be expanded to encompass the age group from birth through 12 , and as the program has developed there is adequate money in the ANC Medical Care Fund to cover this expanded service. SSWB Advisory Committee on Medical Care, Minutes, Aug. 27, 1958. Pediatric care to well pre-school children was ruled out on the ground that services to well children would not be justified at the same time that ill persons with certain diseases were excluded. SSWB Advisory Committee on Medical Care, Minutes, Sept. 13, $195 \%$.

${ }^{84}$ SDSW Medical Care Manuat § MC-040.

85 Ibid.

86 Cal. Healter \& Safety Code $§ \S 3000-3355$. 
those who have contracted them. Similarly, mental illness may be treated through state clinics or through county clinics eligible to state subvention under the Community Mental Health Services Act. ${ }^{87}$

With respect to some of these diseases more than others, the evidence of the adequacy and availability of existing modes of treatment and existing facilities was far from satisfactory, let alone conclusive. In the case of tuberculosis, for example, there appear to be new therapies which make it possible to treat many patients safely and efficiently in their homes after only a short period of hospitalization. If the medical care fund were available to cover the cost of such treatment, it was argued that it would be likely that the number of patients voluntarily submitting to treatment would increase and that the number evading the enforcing authorities would decrease. ${ }^{88}$ The compulsory treatment provisions of the tuberculosis law apply only to the active case already known to the Health Department and known or suspected to be in an infectious stage. As to all others, the voluntary use of county medical facilities turns on the same factors of distance, transportation, opportunity and knowledge of their availability as govern the use of such facilities by those having other diseases. ${ }^{89}$

The exclusion from the fund of maternity care also involved one theory of treatment as against others in addition to questions of the availability of existing facilities. Aid to Needy Children mothers are eligible generally for delivery at county hospitals, and for some prenatal care from county hospitals or local public health clinics. The inadequacy of this prenatal care in quantity, quahty and eligibility to receive it was revealed and documented by a survey of the Public Health Department. The lack of prenatal care obtained by mothers dehivered in county hospitals is associated with higher death rates and hospitalization costs for these same mothers and their babies. Good prenatal care-medical, nutritional and social-is regarded as an effective preventive of premature births and prematurity which are associated with two-thirds of early infant deaths, one-half of fetal deaths, much hospitalization of abnormal newborns, and increased numbers of congemital defects, cerebral palsy, mental retardation and other long-term crippling effects. ${ }^{90}$ Notwithstanding, it was argued that delivery is a hospital procedure and the doctor who performs it should have been in cliarge of the patient all along. If the recipient could choose her own doctor for prenatal care to be paid for from the fund, the medically

87 Cal. Stat. 1957, c. 1989, CAE. WELF. \& INST. CODE $\$ \S 9000-58$.

88 Letter to George K. Wyman, Director, Dept. of Social Welfare, from John L. Gompertz, M.D., President, California Tuberculosis \& Health Ass'n, Aug. 20, 1957.

${ }^{89}$ SSWB, Verbatim Minutes, Aug. 2, 1957.

90 Public Prenatal Care in California (Bureau of Maternal \& Child Health, State Dept. of Public Health, processed, Feb. 1957). 
desirable continuity of prior and subsequent service might more often be broken. In part, at least, therefore, the exclusion of maternity care rested on the conclusion that non-continuous prenatal care is not better than none. The controlling factor, however, was fiscal though the total amount of money per year was not great. Roughly ten per cent of the county hospital dehveries are for recipients of Aid to Needy Children. On the basis of an annual total of 37,421 deliveries in county hospitals, the number of ANC dehiveries can be estimated at 3,700. Assuming an average of two prenatal visits per live birth, a greater utilization of prenatal medical services and the consequent additional laboratory services, the total annual cost would be about $\$ 80,000 .^{91}$

In addition to lome and office visits, the other major item covered by the medical care fund is drugs and medicines. It was estimated at the outset that supplying the need for drugs would be approximately equal in cost to supplying medical services. Brief experience under the act has shown that it is less costly. ${ }^{92}$ Once the principal decision was reached to include drugs and medicines, fewer subsidiary questions of inclusion and exclusion were raised than in the case of medical services. All persons authorized to write prescriptions under the California Plarmacy Lawi.e., plysicians, dentists and chiropodists-were authorized to do so under the medical care program. ${ }^{33}$ Payments are to be made exclusively to pharmacies except where, because a pharmacy is not available, a physician finds it necessary to dispense the drugs. ${ }^{94}$ Drugs are usually furnished recipients who are patients in hospitals as part of treatment. In the first few months of the operation of the medical care fund, the State Social Welfare Board thought it cautiously wise to say that only drugs listed in

${ }^{91}$ SSWB Advisory Committee on Medical Care, Minntes, Sept. 13, 1957. In view of the underexpenditure of ANC medical care funds, the considerations above adduced have led the Medical Care Advisory Committee at this writing to recommend to the State Social Welfare Board that prenatal maternity care, and treatment of tuberculosis and venereal disease be included within the services covered by the fund. SSWB Advisory Committee on Medical Care, Minutes, Aug. 13, 1958.

82 Payments made for the three months ending June 30, 1958 total the following: Physician- $\$ 3,497,091$; Other practitioners- $\$ 484,464$; X-ray $-\$ 343,086$; Laboratory $-\$ 371,563$; Home Nursing - $\$ 120,299$; Rehabilitation- $\$ 8,839$; Dental care- $\$ 305,214$; Other- $\$ 40,966$; Prescriptions- $\$ 3,984,970$. SDSW, Statistical Summary of Medical Care Payments for Public Assistance Recipients in California, June 1958.

${ }^{93}$ SDSW MEdicaI Care MaNuar $\$ M C-046$. The nature of vitamins and the fact that chiropractors cannot write prescriptions gave rise to a cnrions complication. Vitamins may be a food supplement or a drug, depending upon the use. If used to fortify a person's normal or therapeutic diet, they are a food supplement. If used for inedicinal or therapeutic purposes, they are a drug. Thus physicians may prescribe them and payment will be made from the fund. When procured from pharmacists on orders of a chiropractor payment may not be unade from the fund, a circumstance which the chiropractors thought discriminatory. SDSW OID AGE SECURTTY HANDBOOK $§$ A-204.03.

94 SDSW MEDICAL CARE HaNdBoors \& MC-031.1. 
the three standard formularies, would be paid for and to impose time and quantity limitations. ${ }^{95}$ Experience with the program, however, soon showed that such restrictions were not practical. Most physicians prescribe by brand name and the necessity to determine whether the ingredients were in the formularies proved an irksome waste of time. Moreover, it was found that monetary savings could be effected by prescribing some medicine for chronic illnesses in greater quantities than had been permitted. Regulations were accordingly modified to leave the type and quantity of drugs to the discretion of the practitioners, subject to a number of general guides: expensive proprietary items could not be prescribed when less expensive items would serve as well; the quantity prescribed should be the most economical in the circuinstances of each case. ${ }^{96}$ Also repealed after a short time was a rule which permitted counties to direct recipients to obtain their drugs from county-owned dispensaries. ${ }^{97}$ The California Pharmaceutical Association objected to this rule as violative of the recipient's freedoin of choice. The statute does not require free choice of vendors other than physicians. The free choice policy, however, was thought desirable in this area as well. Accordingly, also, a proposal by retail pharmacy interests to prohibit the dispensing of drugs by public clinics was rejected. ${ }^{88}$

\section{Prior Authorization}

Would the amount of money in the fund be sufficient to cover expenditures even as thus drastically himited? No one could say. The exact proportions of the need for any or all of the proffered items, the extent to which recipients would avail themselves of the goods and services listed, the fixed or fluctuating nature of the demand, the length of time it would take to acquaint recipients and supphers with the arrangement, the extent to whicl physicians, dentists and other service vendors would participate in the program at all or if they did the extent to which they would maintain quantity and quality standards in their services to recipients-all of these controlling elements in estimating expenditures, to say nothing of achieving program objectives, were substantially imponderable. As the program was set in motion, therefore, no rehable prediction could be made with certainty as to whether authorized disbursements would stay

95 SDSW Medical Care MandaI §§MC-031.1, MC-031.2, repealed, SSWB, Minutes, Nov. 21, 1957.

96 Ibid. A proposal to require prior authority for prescriptions over a certain amount, say $\$ 6$ or $\$ 8$, or for certain specific expensive groups of drugs such as cortizone, tranquillizers, mycins and hydrazides, was considered and discarded as not practical. SSWB Advisory Committee on Medical Care, Minutes, Nov. 6, 1957.

87 SDSW Medicat Care Manuad § MC-022, repealed, SSWB, Minutes, Sept. 26, 1957.

88 SSWB Advisory Committee on Medical Care, Minutes, Nov. 6, 1957. 
within deposits. In this situation, the alternatives were either to let matters take their course and impose additional limits on items and quantities as they proved necessary or to devise and institute additional controls at the outset. In view of the difficulties of curtailing services once offered, prudent management dictated the latter course. This is what was done. Additional controls were created, not, however, in the form of additional specific exclusions from the already sharply pared down list of items to be provided. Rather expenditures in the case of any given recipient were to be controlled. Since, as indicated earlier, this could not be done by setting a fixed maximum in dollars or otherwise, purely discretionary power had to be granted to local officials to be exercised case by case. A system of prior authorizations was established which would apply primarily to services and only incidentally to drugs. Two lists were prepared: one of the kinds and quantities of services which would be paid for if supplied without prior authorization, ${ }^{99}$ the other of services which would only be paid for if specific permission to supply them were secured in advance. ${ }^{100}$

90 SDSW Medicar Care Mavuat § MC-031.1: Without Prior Authorization.

A. Home and/or office visits from or to practitioners (other than dentists or chiropodists) to a limit of three such visits for any ... [one] illness, or within 90 days from the first visit, whichever is less.

B. Dental services, including extractions and prescribed drugs, required for the relief of pain, or the elimination of acute infection.

C. Drugs, as prescribed by practitioners except alcolnolic beverages.

...

Medical supplies, if prescribed by a practitioner, and listed in the schedule of maximum allowances.

D. Laboratory services for urinalysis and blood counts.

E. Laboratory and X-ray services as prescribed by the practitioner in an emergency.

F. Emergency surgery not requiring hospitalization under accepted inedical standards.

G. Services of visiting nurse associations to a inaximum of five visits for any one illness.

H. Chiropody services of an einergency nature, including the prescribing of drugs for relief of pain or elimination of acute infection. Such emergency care to be justified by written report from the treating chiropodist. 100 Id. \& MC-031.2. With Prior Authorization.

A. Home and/or office visits from or to practitioners (other than dentists and chiropodists) in excess of three such visits for any one illness or beyond the 9oth day from the first visit.

B. Any service rendered by chiropodists.

C. Special inedical supplies not listed in the schedule of maximum allowances, but required as a part of a specific treatment plan.

D. Elective laboratory services other than urinalysis and blood counts.

E. Elective radiological services.

F. Elective office surgery.

G. Services of private nurses or services of visiting nurse associations in excess of five visits for any one illness.

H. Dental care for children aged 5 througl 12 years as necessary to prevent tooth loss.

I. Complete histories and physical exammations by physicians.

J. Services of physical therapists as prescribed by physicians.

$\mathrm{K}$. Services of rehabilitation centers meeting the standards of the Bureau of Vocational Reliabilitation. 
The main feature of the first list was its limitation of home and office calls to three for any one illness or within a ninety-day period. In general, if the plan of treatment of any patient is extensive and involves a great deal of time or money, or if visits exceed three for any one illness or within a ninety-day period the plan has to be submitted to the county welfare department for approval and authorization. The county medical or dental consultant assists in processing these plans. ${ }^{101}$ No standards are laid down to guide or govern the discretion of the county welfare department or even to indicate whether financial, medical, welfare or administrative factors should be given consideration. It was contemplated that such standards would be established as rapidly as experience and accumulation of data made this possible.

This system of prior authorization has given rise to the sharpest criticism of the medical care program yet to appear. The criticism has not been directed to the specific cases in which approval has been granted or withheld or to the policy lines beginning to emerge as individual decisions form a pattern. It is directed rather at the need to secure authorization at all. The protest is that the system institutes a political control of the practice of medicine, involves unnecessary red tape and causes delay in the treatment of patients. ${ }^{102}$ Since in the first four months of operation of the program expenditures remained within bounds and since during that period the operation of the program provided data as to the list, it became possible in the Spring of 1958 safely to experiment with a selective relaxation of controls. Four counties, involving about twelve per cent of the caseload, and representing various conditions, were chosen in which to determine the effects of eliminating the prior authorization requirement. ${ }^{103}$

The results of the test after four months of operation were striking: prior authorization did not achieve its intended objective of conserving funds. Expenditures from the fund in the demonstration counties remained roughly in the same relationship to expenditures in control counties that had prevailed earlier. In the control counties practically all requests for authorization were approved "as is" or were modified only in the sense that arbitrary time limits were set on thein. An analysis of requests for authorization made by the State Department of Social Welfare, slowed that only an extremely small proportion were refused or modified to any extent. Furthermore, the secondary objective of prior authorization, namely, to prevent abuse of the program by individual practitioners, could be achieved as well, it was found, by an adequate system of medical postaudit. $^{104}$

101 Id. § MC- 052 .

${ }^{102}$ See SSWB, Summary, Feb. 20, 1958. See also resolution of the Los Angeles County Medical Association dated Feb. 3, 1958.

${ }^{103}$ SSWB, Minutes, Feb. 20, 1958.

${ }^{104}$ SSWB Advisory Committee on Medical Care, Agenda, Aug. 27, 1958. 
The upshot of the prior authorization demonstration project doubtless will be the drastic alteration or complete abolition of the prior authorization requirement. The staff of the State Department of Social Welfare argues that pending further experience with a system of post-audit controls and other fiscal policies the relaxation of the requirement should be gradual, remaining in effect for selective items and amounts. Among these might be: (a) elective office surgery-because it is costly to perform, is sometimes not in accordance with local practice, and is frequently of cosmetic rather than of medical value; (b) rehabilitation center services-because they require careful coordination of medical and social planning which is in itself costly, and because, although experience in their use under the program so far has been limited, they could command a large portion of the fund if their availability were emphasized; (c) X-ray and laboratory procedures, because they represent a continual temptation to the practitioner who, in his eagerness to take full advantage of all possibilities for detecting illness may utilize them when they are not specifically called for; (d) special medical procedures-because they are costly, should be used judiciously, and are potentially more subject to abuse than are most of the other services; (e) visits for the treatment of chronic illnessesbecause they represent such a heavy part of all practitioners visits and their control through required authorization after a fixed number of visits would lift most authorizations and still keep the lid on the fund. The evidence, however, that prior authorization is not an effective fiscal control is so striking that complete abohition of the requirement within the near future seems likely. In addition to the evidence drawn from the demonstration project and from the departmental analysis of authorization requests, there is the fact that expenditures from the aged and blind medical funds have exceeded deposits-the over-expenditure rate in the aged program is $\$ 40,000$ a month, in the blind program $\$ 5,500 .^{105}$ The only feasible method of control seems to be by removing additional items from the list of covered goods and services or by adding more stringent restrictions on times and quantities.

Apparently the doctors prefer a rejection of a bill on an audit after the service has been rendered to prior notice that the bill will not be paid if the notice is connected with a requirement of applying in advance for approval. Yet both methods, viewed as policing methods to enforce standards of medical practice on individual practitioners, are subject to the identical weakness: namely, the complete absence of any established standards and, therefore, the presence of a discretionary determination in each case. The presence of this element of unguided discretionary power ad-

105 In the children's program there is an underexpenditure of $\$ 200,000$ a month. SSWB Advisory Committee on Medical Care, Minutes, Aug. 27, 1958. 
ministratively and as matter of policy is undesirable. It is, however, unavoidable until experience under the program makes it possible to develop guides and standards. When such guides and standards become possible, a system of prior authorization would be rendered at once effective and umiecessary-if the standards and guides can be laid down, they can then be administered in the same manner as other rules without the necessity for permission in advance. In a post-audit system, considered solely as a policing procedure to guard against improper practice, the presence of unguided discretion is complicated by still another question: who should exercise the discretion-local government officials or committees of the medical societies and other practitioner groups which serve as the normal instrumentalities for enforcement of standards of ethical and medically proper practice? Opinion on this question is sharply divided. The medical societies favor investing final pohicing authority in the hands of their committees and final auditing authority in the hands of the Califorma Physicians Service. Sonie county welfare administrators also favor this course as the most efficient method of administration and the surest way of developing harmonious relations with the medical societies. On the other hand, how far can, and how far slould, such policing power in a government program and such final authority to pay bills out of government funds be delegated to private groups and organizations? Among government officials, the attitude is not widespread that government can or should divest itself of such governmental responsibilities. In the process of relaxing or removing the prior authorization requirement and establishing alternative methods, these questions yet remain to be decided.

\section{PraCtitioners AND FeES}

The goods and services to be provided under the program and the fact that the services are to be provided only in homes and offices determine to some extent the list of practitioners eligible for vendor payments from the fund. Within these rather substantial limits, however, the State Social Welfare Board sought not to interpose its judgment as to the health value of services rendered, the treatment and functions to be performed by the various practitioners, or the jurisdictional line between them. Sucli matters were left to the laws and officials governing the issuance of licenses and the conduct of practice. ${ }^{106}$ This is in accordance with the legislative mandate to allow as far as practical, efficient and econonical, free choice of practitioners and not to discriminate against the non-medical healing arts. The

106 Even so, borderline cases had to be resolved, e.g., see the discussion by the SSWB's Medical Advisory Committee about whether certain allergy testing, the drawing of blood, and certain laboratory procedures might be properly included in a chiropractic schedule. SSWB Advisory Committee on Medical Care, Minutes, Sept. 13, 1957. 
eligible practitioners include medical and osteopathic physicians, dentists, chiropractors, chiropodists, physiotherapists, nurses and healers by prayer or spiritual means. ${ }^{107}$ The regulations define practitioners in terms of their license. ${ }^{108}$ To this those who heal by prayer or spiritual means are a statutory exception..$^{100} \mathrm{~A}$ provision with respect to chiropodists that they will be paid from the fund only if the patient is referred to them by a physician could only be justified on a particular view of the merits of the practice of chiropody and its relationship to the general practice of medicine, a subject upon which both chiropodists and physicians expressed themselves strongly. Chiropodists are independently licensed and are authorized to diagnose diseases. Accordingly, a regulation making vendor payments to chiropodists dependent on whether the patient was referred to them by a physician whicl at first found its way into the administrative manual was soon removed. ${ }^{110}$ Not so, however, as concerns the physical therapists. Despite their protest, a rule making reference by a physician a condition precedent to covering their services by the fund was adopted and has reinamed in effect. ${ }^{111}$ Physical therapists are not pernitted to diagnose diseases and this influenced the decision. The controlling factor, however, was that this requirement was regarded as a suitable if not necessary means of himiting withdrawals from the fund. The request of the chiropractors that the counties, in their administration of the medical care program, be required to avail themselves of the services of chiropractic consultants as they are of nedical and dental consultants was rejected. ${ }^{112}$ This was justified by the small volume of chiropractic services rendered to public assistance recipients in most counties and the total absence of chiropractors from some counties.

Setting the prices and fees to be paid by the medical care fund for the goods and services purchased, anticipated at the outset as perhaps the thorniest of the problems to be encountered, proved in the end no more difficult, theoretically and practically, than several of the others. The fee and price schedules were worked out in the course of discussions with the relevant professional associations - the California Medical Association, the California Dental Association, the California Association of Chiropody, the California Chiropractic Association, the Physical Therapists Association, the California Optonetric Association, the Visiting Nurses Association, the California Pharmaceutical Association. Inevitably, there was an element of negotiation and bargaining in the process. That element, how-

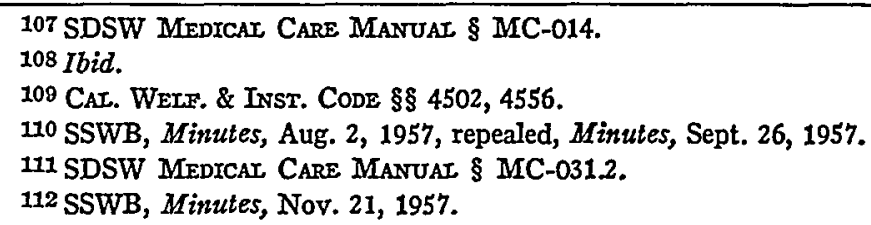


ever, was not controlling; indeed, it turned out to be fairly minor. Broadly, the factors governing decision for the department and in varying degrees for the respective associations were these: (1) The money in the fund should be stretched as far as possible to procure the needed goods and services in reasonable quantities and quality for the greatest number of recipients. (2) At the same time, this did not mean setting the lowest price anyone could pick out of the air or find actually being charged. The vendors were entitled to a reasonable compensation for their services or profit on the sale of their goods. This was a matter both of desirable public policy and practical necessity. Whatever agreements might be reached with the professional associations, fees would lave to be high enough to induce individual practitioners in great numbers to take public assistance clients-often regarded by practitioners as a group least desirable among patients - and provide them with care pitched at reasonably high levels. Cut-rate prices could not be expected to gain the desired participation by the practitioners and stretching the fund too far would only frustrate its program objectives. (3) Fees would have to be at least somewhat lower for public assistance recipients than those paid by the taxpayer himself if continued public support for the program were to be forthcoming over the years. In effect, this calls upon practitioners as a selected group to assume a portion of the public obligation to care for the needy and the principle was questioned on that ground. Generally, however, it was received as the simple translation into a public program of the historically developed and socially accepted obligation of those engaging in the healing arts. (4) The fee schedule slould not be sucli as to add to the general inflation of medical care, either in terms of absolute prices or through the dilution of the product. To say that these often conflicting elements were the factors goverming decision is, of course, to give no key to the weight attributed to each. As a practical and procedural matter, however, following either of two methods produced very much the same results; starting with the fee schedule actually being charged and making a reasonable discount because of the welfare character of the program; starting with office costs and adding a reasonable amount which would enable the practitioner to spend his time if it would not make it profitable for him to do so.

The fee schedule for medical services was actually determined on a basis of the so-called relative value scale established by the California Medical Association in 1956 and worked out in the preceding years. In this scale, all medical services and procedures are related to each other according to the amount of time involved, the cost to the physician, and the fee actually charged in California. Thus, for example, the more complex office visit requiring history and examination to determine diagnosis 
and treatment is twice the routine office visit. The basic unit is $\$ 5$. The values that are related in the scale are monetary not medical or health values. The first premise is the current actual charge. This was determined when the scale was established by a questionaire sent out to 12,000 physicians. The returns showed that there are four plateaus in the state with respect to fees but that within each the fees stand in the same relative positions. In order to avoid the inflationary effects in the low-priced areas of a uniform statewide fee schedule which, to be everywhere effective, would have to be tied to fees in the ligher-priced zones, much consideration was given to the possibility of varying the fee according to the plateau. ${ }^{113}$ However, five-sixths of the public assistance recipients live in areas where the basic unit is $\$ 5$ or more and only one-sixth in areas where the basic unit is $\$ 4$ or less. Conforming to the plateaus thus would be administratively costly without being particularly helpful to many recipients. The extent to which physicians in the low-priced areas will charge the maximun statewide fee permitted for public assistance recipients, and, if they do, the inflationary effect of this on the fees charged to other patients will be revealed as time goes on and the program manifests itself in operation. Such consequences are regarded as very likely. Therefore, the cost of the basic unit was accepted as $\$ 5$ state-wide. A 20 per cent reduction was established as proper because of the welfare character of the program, setting the basic unit of $\$ 4$ for public assistance recipients. ${ }^{114}$ It costs the average physician, according to the California Medical Association, $\$ 3.50$ per patient call for the cost of his office, staff and equipment. Hence, the compensation for his time is $50 \mathrm{c}$ per patient call, a fee hardly to be regarded as excessive if, indeed, it can be counted adequate.

By a similar process, though generally less elaborate with respect to other practitioner groups, fees were set for chiropractors, chiropodists, dentists, physical therapists and visiting nurses. With respect to many of these groups, less extensive and up-to-date figures were available as to the price level currently in existence. The chiropractors sought insistently to secure the same fee schedule as physicians, but were held to a basic unit fee of $\$ 3.500^{115}$ The cliropodists sought a somewliat higher fee schedule than physicians in several categories. ${ }^{110}$ The fees for healers by prayer and spiritual means were set after discussion with the Christian Scientists, they being the only ones to have qualified under this provision. Only two items were covered: $\$ 3$ for office visits; $\$ 4.50$ for home visits. ${ }^{117}$ Several small sects have applied but have not been able to establish that

113 SSWB, Verbatim Minutes, Aug. 2, 1957.

114 SDSW Medicat CaRe Manual \& MC-040.1.

116 Id. \& MC-044.

116 Id. \& MC-043.

117 Id. \& MC-045. 
they are bona fide organizations depending entirely upon spiritual means. The Christian Scientist Church has now decided that acceptance of money from the medical care fund may violate the primciple of separation of church and state and has instructed the practitioners to desist from making claims against the program. The allowance for drugs and medical supplies was set at 10 per cent less than the fee schedules generally in use by Califorma pharmacies, which equals a 20 per cent reduction from the average professional fees and markup. ${ }^{118}$ Since public and voluntary chinics operate without a profit and generally at lower operating costs per patient call than private physicians, they are allowed only 75 per cent of the fees charged by private practitioners. ${ }^{119}$

These fee schedules do not provide a system of set fees. Rather they are maximum amounts to be paid from the fund for the specified service or procedure. ${ }^{120}$ The objective of the medical care program, that is, securing needed medical care for public assistance recipients who lack private resources out of which to purchase it, would be frustrated at least in part if practitioners were allowed to charge recipients for any given service an amount in addition to that received from the fund. Accordingly, although the medical care statute is silent on this point, the regulations provide that "no additional charge to the recipient will be permitted.".121

\section{Administrative- Legal Problems}

The inplementive problems thus far discussed involved large issues of medical and welfare policy primarily and only imcidentally administrative and legal ones. The two remaining major items in connection with the new medical care program to be discussed bring administrative and legal problems much more dominantly to the fore. The first of these had to do with the use of California Physicians' Service as a fiscal agent. The audit and payment task under the new program promised to be of colossal proportions involving hundreds of thousands of small bills each month. Partly because of the magnitude of the task and the experience of California Physicians' Service im handling such an operation, and partly as a means of maintaining favorable relations with medical practitioners by handling the billing process, so full of red tape and annoyance at best, through their familiar channels, the Department proposed to consummate a contract with CPS, a private corporation, constituting it a fiscal agent

118 Id. \& MC-046.

119 Id. \& MC-041.

120 Id. \& MC-040.

121 Ibid. See the legal opinion of the Department upholding the validity of this regulation in response to a question asked by the California Physicians' Service as to whether a physician who does not wish to abide by the public assistance schedule of maximum allowances may require the recipient to pay an additional fee. SDSW, Circular Letter No. 858, issued Jan. 16, 1958. 
to take care of billing, auditing and payment. Relationships with dental practitioners would be maintained through the California Dental Service Corporation with whom CPS has a subcontract. Under the contract, CPS would receive invoices from the individual vendors, subject them to medical and fiscal audit and send a weekly consolidated invoice to eacli county. The counties would make payment to CPS in a lump sum and CPS would then pay the individual vendors. The counties would be required to reimburse CPS monthly for the actual cost of administration. CPS would also be responsible for other coordination, administrative and statistical functions. The Department would enter into the contract for and on behalf of the counties. All counties would be included in the arrangement. Vendor groups not normally connected with CPS, such as liealers by prayer, chiropractors, visiting nurses and public clinics, would bill the counties directly and be paid directly by them.

The County Board of Supervisors Association and the welfare directors of a number of counties, including Los Angeles, interposed a strong objection to the proposed contract on legal and policy grounds. ${ }^{122}$ The matter was referred to the state Attorney General who ruled that the Department might lawfully enter into the contract but only for and on behalf of such counties as were willing to participate. ${ }^{123}$ On this basis, the contract was executed. Thirty-five of the fifty-eight counties in the state have elected to accept its provisions. One of these counties has since given notice of withdrawal and others have indicated that they may withdraw on the basis that the benefits received from CPS are not commensurate with the cost. The Department was not sufficiently sure of the administrative, fiscal and public relations merits of the contract as initially proposed to proceed with it in the face of the adverse opinion of the Attorney General. The Department's own legal advisor was convinced that the department liad the authority to do so.

In view of the opinion of the Attorney General and the submission of the Department to it, the substantial legal questions presented by the compulsory contract cannot now be finally adjudicated. Los Angeles County had announced its intention to seek judicial review. Some of the questions persist in justiciable form with respect to the contract as put into effect but the most interesting one of them has been watered down and the number of agencies with adversary standing and motivation to test them has been greatly reduced.

The legal issues are both statutory and constitutional. The medical care statute explicitly vests contracting authority both in the State De-

122 SSWB, Minutes, Aug. 2, 1957.

12330 OPs. CaI. ATT'y GeN. 75 (1957). 
partment of Social Welfare and in the counties. ${ }^{124}$ Are these two grants duplicatory and, if so, when exercised in conflict, which prevails? Though on this point the Attorney General's opimion is virtually without analysis, he concluded that the grants might be exercised in contradictory ways and that the state authority is subordinate to the county. Yet, the State Department of Social Welfare is given "full power to supervise every phase of the administration" of the program; ${ }^{125}$ the contracting authority of the state relates explicitly to fiscal administration, that of the county seems more generally to cover, though not necessarily to be confined to, providing the medical care services to the recipient; and the county contracts are required to "comply" with the subsection authorizing the state contracts and with the section vesting the State Social Welfare Board with power to "prescribe the policies and scope of the services to be provided" and to make the rules and regulations "necessary for carrying out" the program. ${ }^{126}$ The services encompassed by the CPS contract are services of administration. The statute clearly assigns administrative functions and the cost of paying for them to the counties. ${ }^{127}$ The specific power vested in the State Department of Social Welfare to make contracts of this nature, therefore, it would seem, could only be exercised for and on behalf of the counties and could only be made effective if the counties were obligated to conform to and carry out the terms of any contract so made. On the whole, the issues of statutory construction, contrary to the opinion of the Attorney General, seem rather easily to resolve themselves in favor of the existence and predominance of the state authority. It is at that point that the difficult problems are met and this may explain the character of the Attorney General's opinion. Counties are agencies of the state. They may be required by the state to undertake various programs including welfare programs. The state may even direct them to pay for the support and administration of such programs out of their own funds. ${ }^{128}$

124 "(a) The State Department of Social Welfare may enter into nonexclusive contracts providing arrangements under which funds available for medical care under this chapter shall be administered and disbursed to providers of medical care in consideration for services rendered and supplies furnished by them in accordance with the provisions of the applicable contract and any schedule of charges or formula for determining payment establislied pursuant to such contract....

"Nothing in this section slall prevent any county in providing services required of it under this chapter from entering into contracts with another county, with one or more nonprofit memberslip corporations organized and operating under Section 9200 or 9201 of the Corporations Code, with inedical societies, with medical groups, or with vendors of medical supplies except that such contracts shall comply with subdivision (a) or subdivision (b) of this section and with the scope and rules prescribed by the State Social Welfare Board pursuant to Section 4555 of this code." CAL. WeLF. \& INST. CODE $\$ 4554$.

125 CAL. WELF. \& INST. CODE \& 103.7.

120 CAL. WEIF. \& INST. CODE $\$ 4555$.

127 CAL. WELE. \& INST. CODE $\$ \S 4550,4602-05$.

128 County of Sacramento v. Chambers, 33 Cal. App. 142, 164 Pac. 613 (1917); City \& County of San Francisco v. Collins, 216 Cal. 187, 13 P.2d 912 (1932). 
Can the state, however, constitutionally go one step further and make a contract on behalf of the counties to pay for and carry out these governmental functions and purposes through a private corporation? It is this question from which the sting was removed when compulsory county coverage was dropped from the CPS contract.

The constitutional provisions bearing on the remaining questions about the validity of the contract relate to the delegation of county governmental functions, state and county civil service and the lending of governmental credit.

Section 13, article XI of the state constitution forbids the legislature to delegate "to any special commission, private corporation, company, association or individual any power to make, control, appropriate, supervise or in any way interfere with any county, city, town or municipal improvement, money, property, or effects, whether held in trust or otherwise, or to levy taxes or assessments or perform any municipal function whatever...." It was the Attorney General's opinion that the medical care statute and CPS contract were saved from invalidity under this prohibition by the "well recognized state purpose exception" to it. ${ }^{129}$

Little constitutional difficulty is presented by article XXIV dealing with the state civil service and construed as banning contracts with private firms for services to the state unless the services are of a temporary nature and cannot be performed by state employees. ${ }^{139} \mathrm{CPS}$, pursuant to the contract, performs services for and on behalf of the counties, not the state. This, however, merely avoids the Scylla of state civil service requirements to encounter the Charybdis of county charter provisions on the same subject. If the contract as made for and on behalf of the counties, and if the counties exercising the contracting authority for themselves would be limited by their civil service charter provisions, can the state by the contract do what the counties themselves could not do? A negative answer is strengthened by the fact that the contract is not forced on the counties but they enter it and accept its provisions voluntarily. However, the specific authorizations in the statute to the state department of social welfare to enter the contract, ${ }^{131}$ buttressed by the statewide character and concern of the over-

12930 Ors. Cax. Atr'y Gen. 75, 77 (1957) ; Pixley v. Saunders, 168 Cal. 152, 141 Pac. 815 (1914); City of Los Angeles v. Post War Public Works Review Board, 26 Cal. 2d 101, 156 P.2d 746 (1945); Polk v. City of Los Angeles, 26 Cal. 2d 519, 159 P.2d 931 (1945) ; 27 Ops. CAI. ATT'Y Gen. 15 (1956).

The only case cited by the Attorney General is in point for the "state purpose" proposition but involved a substantially dissimilar situation with respect to the type of agency involved. County of Sacramento v. Chambers, 33 Cal. App. 142, 164 Pac. 613 (1917) involved a state board appointed to administer a fund granting aid to cities and counties for the support and care of persons suffering from tuberculosis.

130 Ops. Cax. Att'y Gen. 10292 (1935) and N.S. 2219 (1939) ; 24 Ops. Cax. Atr'y Gen. 173 (1954).

131 CAX. WELF. \& INST. CODE § 4554. 
all medical care program, would seem constitutionally sufficient to enable the contract and the statute to transcend local charter limitations.

The constitutional prohibition on the lending of credit "for the payment of the liabilities of any individual, association, municipal or other corporations whatever" would hardly seem applicable. The moneys advanced to CPS are not for the payment of its liabilities. CPS can make disbursements from the funds entrusted to it only in payment of the obligations of the government pursuant to the medical care program.

The other major implementive problem raising complex administrative and legal issues involved the relationship between the Medical Care Fund and "special needs" grants and allowances. A public assistance recipient who has income of his own from Old Age, Survivor's and Disability Insurance, earnings, insurance, pensions, responsible relatives or other sources is allowed to retain it to meet his needs. The basic aid grant is intended to cover basic needs-i.e., needs common to all recipients: food; lrousing and utilities; houselrold maintenance; clothing; transportation; incidentals; education and recreation; medicine chest supplies. ${ }^{132}$ Other needs recognized in the welfare laws and regulations are not common to all recipients. They arise out of physical infirmities or other conditions peculiar to the individual's circumstances. These may be for items not treated as basic needs or for greater amounts to meet the cost of basic needs. ${ }^{133}$ These are called "special needs." They include: board and room; board and personal care; moving; housekeeping service; yard care; laundry service; telephone and medical care. ${ }^{134}$ If a recipient has outside income inore than sufficient to meet his allowable special needs, the amount of his aid grant is reduced thereby. In 1957, the Legislature amended the Old Age Security Law to provide an amount up to $\$ 16$ per month to meet needs not met by the basic grant. ${ }^{135}$ Thus, a recipient without private income with which to meet his allowable needs above the basic aid grant may receive a limited aid grant for that purpose. ${ }^{136}$

The problems of administrative policy and legal interpretation raised by this already existing and now newly augmented system of special needs, grants and allowances were: (1) Should the extra aid grant be placed upon the same footing as outside income declared by the Legislature to render a recipient ineligible for fund services if the services could be purchased

132 SDSW Otd Age Securtiy Manuat \& A-202.

133 Id. \& A-203.

134 Id. \$\$ A-204 through A-207.

135 Cal. Stat. 1957, c. 2411, CAL. WeIf. \& INST. Code $\$ 2020.002$.

130 Vendor payments from the Medical Care Fund and cash grant payments for medical care, by program and type of care, during April-June 1958, are set out in tables 5 and 6 (see Appendix at page 597) from SDSW Statistical Summary of Medical Care Payments for Public Assistance Recipients in Calif., June, 1958. 
as a special need? (2) Among the various special needs, should items of medical care be met first or last with outside income and/or the extra grant when determinimg eligibility for fund services? (3) In this connection, how should items of medical care not covered by the fund be treated? (4) How should the split payment cases be handled-i.e., cases in which a recipient had sufficient grant or outside income to meet only part of his need for a particular item of medical care covered by the fund?

The first of these questions-whether the extra grant and outside income should be treated the same-the Social Welfare Board answered in the affirmative. In providing for the extra grant, the Legislature had evidently intended to improve the situation of those recipients who have only the aid grant relative to those who have the grant and some outside income. The availability of the extra grant and its amount was therefore made by the Legislature dependent on the presence or the amount of outside income. Accordingly, the Social Welfare Board made the extra grant subject to the rules governing application of outside income to the meeting of special needs including the special need for medical care. ${ }^{137}$ The federal officials at first held this arrangement in which the same iteins of medical care could be secured through the fund and through the cash grant in violation of federal regulations. After a temporary threat to withhold federal funds and protracted reconsideration, however, they withdrew their objection and approved the plan.

In order, on the one hand, to make full use of the individual's own resources as directed by the Legislature, and, on the other hand, to carry out the major purpose of the new program to increase the amount of medical care made available to public assistance recipients, while at the same time not worsening the situation of recipients with respect to the special needs provisions, the following priorities were established: Outside income of the recipient is applied first toward meeting non-medical special needs and medical needs not covered by the medical care fund. Next it is applied toward meeting medical needs covered by the medical care fund. Lastly it is applied toward meeting basic needs, i.e., to reduce the amount of the aid grant. Similarly, the extra grant money is applied first toward ineeting nonmedical special needs and medical needs of a type not covered by the fund and thereafter to medical needs covered by the fund. Thus, under the regulations as they now stand, the public assistance recipient eligible to receive medical care paid for out of the new medical care fund is one who has cash resources in addition to his basic aid grant but which are not available to meet the cost of fund-covered medical needs. The cash resources may consist entirely of outside income, partly of outside incoine and partly of additional aid grant, or entirely of additional grant. Whatever the source or the

137 SDSW Otd Age SEcuRITy Marval $\$$ A-205 through A-207. 
amount of the cash resources, they are held unavailable to meet the cost of fund-covered medical needs if they are fully committed to meeting nonmedical special needs or medical needs not covered by the fund. Stated in terms of one of the rules about special needs, "cost of an item of medical care of a type covered by the medical care fund shall be allowed as a special need rather than paid from the fund whenever the recipient's aid payment and income for the month will be sufficient to meet his total need including the cost of the particular item of medical care."138 Moreover, such special need allowance is subject to the same limitations on quantity, frequency and cost as would apply if the medical care fund were used. ${ }^{139}$ Purely administrative considerations resulted in two modifications to this general pattern of relationship between the medical care fund and special needs allowances and grants for medical care: payments for drugs and medical supphes are made from the fund regardless of the possibility of providing for them through the special needs device; if a recipient's cash resources are only sufficient to enable him to pay part of the cost of any

138 Id. \& A-205.12.

139 This provision that the vendor must comply with all of the requirements of the program if the recipient is to receive special needs consideration for items covered by the fund has been a fertile source of misunderstandings, complications with individual practitioners and of individual appeals to the State Social Welfare Board. The following will illustrate a variety of situations.

SSWB, Agenda, April 24, 1958, Case No. 42: Appellant bad been receiving care from lier doctor for many years. He dislikes the medical care program and, fearing that she will lose him she is reluctant to insist that he coinply with all of the conditions. The rates charged her are within the fee schedule. She is seeking to have allowed as special need prescriptions made out by the doctor on his regular blanks instcad of the county form. Held: appeal demed.

SSWB, Agenda, April 24, 1958, Case No. 71: Appellant received medical care from the University of California Hospital Clinic. The medical care item purchased met all of the requirements for allowance of special needs under the program except that the vendor had not become a participating medical facility under the program. The appeal was granted in this case on the special ground that the status of the vendor was peculiarily within the knowledge of the county officials, that the county officials had approved use of the clinic in advance in this case and that, therefore, by a general doctrine of equitable estoppel, the county could not now be heard to plead lack of conformity to the rules as a bar to allowing the special need.

SSWB, Agenda, April 24, 1958, Case No. 69: A chiropractor charged the appellant $\$ 5.00$ a visit, $\$ 3.50$ being the maximum allowed in the fee schedule. Appellant asked that the visits be allowed under the special needs provisions. Appeal demed. SDSW MEDICAI CARE Manuaz $\S$ MC-040 forbids any additional charge to the recipient. In special needs cases this can only be enforced through withholding from the recipient the amount permitted by the fee schedule.

SSWB, Agenda, April 24, 1958, Case No. 31: During the past three years the county imcluded as a special need in the appellant's OAS grant an allowance for 2 ounces of whiskey per day prescribed by his doctor for a heart condition. Under the medical care program, SDSW Medrcar, Care ManUal \&MC-031.1, alcoholic beverage prescriptions are not covered by the medical care fund. However, SDSW OLd Age Security MaNual \& A-206.12, provides that the cost of drugs, therapeutic preparations and medical supplies dispensed, prescribed or recommended by a practitioner but not covered by the medical care fund are allowed as special needs. Accordingly, the appeal was granted to allow the prescribed whiskey as a special need. 
particular item of medical care covered by the fund, the fund will meet the entire bill. As will be clear from what has been said so far, the rules relating to the use of the medical care fund when taken in conjunction with the rules governing special needs, including items of medical care, are of such number and intricacy as to tax the most alert caseworker, recipient and vendor of medical goods and services. It was therefore decided not to add to this the further complexities of a system of split invoices. Payments made to cover special needs under the California law must be in the form of unrestricted money payments to the recipient. They cannot be in the form of vendor payments or joint-payee payments. For this reason, if part of an item of medical care were covered by an additional aid grant and part by the fund, the vendor's invoice would have to be split, one warrant being sent to the vendor and another to the recipient with the expectation, or at least the liope, that the recipient would then complete the payments to the vendor. This was avoided by channeling the whole of such payments through the fund, ${ }^{140}$ and by eliminating, as an allowable special need, drugs and medical supplies covered by the fund. ${ }^{141}$

Only the special complications arising out of splitting invoices or the purchase of drugs and inedical supplies liave been eliminated. All of those complications remain which arise out of the fact that there are two systems of payment-the vendor payment from the Medical Care Fund and the cash payments to the recipients for items of care covered by the fund or different items of medical care. ${ }^{142}$ Administrators, caseworkers, practitioners, and recipients, in order to function under the program, must be aware of the fact that there are two systems and must know the rules governing each and their interrelationship. Recipients must promptly report and adequately verify medical needs to have them allowed as special needs. When seeking payment, practitioners must know for what services to look to the recipient and for what to the fund. ${ }^{143}$ Caseworkers and administrators have

140 SDSW Otd Age Security Manuax \$ A-205.13 (Item 1). The rule that the fund would pay all invoices that would otherwise be split between the fund and the special needs grant or allowance had an exception: "If a portion of the fee for services otherwise covered by the Medical Care Fund is paid by the carrier for a person enrolled in a prepaid medical plan, the balance of such fee is allowed only as a special need."

141 There was also an exception to this provision: "When eligibility exists only because of need for drugs and/or medical supplies; i.e., the recipient's income is sufficient to cover all other needs, the cost of such drugs and/or medical supplies when prescribed by a doctor or practitioner is allowed as a special need rather than paid from the fund." Id. § A-205.13 (Item 2); \& A-206.12.

142 The relative rolls of the fund and the special needs allowance in the overall medical care program can be seen from the table (see table 1, Appendix at page 598) released by the State Department of Social Welfare.

${ }^{143}$ In order to circumvent these difficulties, a CMA letter advised doctors that they might accept payment from the patient at time of service and thereafter reimburse him to the extent that the bill was payable from the fund and the doctor received the vendor pay- 
to do the final unravelling. Short of legislative alterations in the programs of medical care and/or special needs, these difficulties will necessarily continue. Whether such alterations should be made, and, if so, which ones, will turn on such factors as the following: an assessment of the importance of retaining, even to the limited extent that it now exists the cash grant principle as against the vendor payment in the field of medical care; the extent to which the basic grant in Old Age Security is increased to meet the cost of living and thus under the present formula to eliminate the possibility of special grants to meet special needs; the willingness of the Legislature to add additional unmatched money to the Medical Care Fund; the weight to be given administrative convenience and feasibility in selecting among alternative substantive policies. The administrative considerations here referred to do not seem to justify the abolition of the special needs system insofar as it allows recipients with some outside inconie inore nearly to meet their needs and thus to mitigate the consequences of the inadequacy of the basic grant.

\section{PARTICIPATION OF THE DOCTORS}

What about the doctors? Without their willing cooperation, the inedical care program could not possibly succeed. Are they participating in such numbers and throughout the communities of the state so as to make the program workable, if not to insure its success? After a year of program operation, the answer is clear: they are, though there are communities in the state in which medical services under the program are either nonexistent or inadequate and though a substantial number of medical societies have adopted and released strongly condemnatory resolutions and memorials. These ranged from emphatic denunciations of the principles involved to categorial votes of non-participation. The fairly typical language of one of these resolutions declared that the program results in: "1. Decrease in local responsibility and control; 2. Degradation of the moral fibre of recipients; 3 . Creation of dangerously powerful welfare department 'medical consultants'; 4. Socialization of medicine; 5 . Increased cost of the taxpayer ...."

In all, thirteen county medical societies, some of which cover more than

ment. If this method were used, the doctor would not have to know what part was vendor payment nor would he have to wait for payment through the recipient after the latter received the cash grant. County auditors objected to this method on the ground that if the doctor has been paid they cannot authorize another payment. Moreover, the method works a hardship on the patient. The doctors are better able to carry the bill than the recipient is to wait reimbursement by the cash grant. The State Department of Social Welfare therefore issued a Circular Letter discouraging the use of the method and advising that collection at time of service should be made only when the doctor has good reason to beheve that the item is allowable as a special need. SDSW Circular Letter No. 864-A (MC) Feb. 26, 1958.

144 Butte-Glenn Medical Society, Mar. 1, 1958. 
one county, took a stand of opposition to the program and recommended various degrees of non-participation by members. In one or two counties located in outlying areas and with little population there has been a virtually complete boycott of the program by the doctors. In one of these counties the doctors have continued to supply their services free or to bill the county under a temporary program. ${ }^{145}$ In almost all of the counties in which the medical societies adopted adverse resolutions, and in all other counties of the state, a substantial percentage of the doctors have supplied and are supplying their services under the program.

The president of the Los Angeles County Medical Society led a move for the complete abstention of the doctors of that county in which over 40 per cent of the state population resides. The move, however, was defeated on the ballot of the members.

The House of Delegates of the California Medical Association voted to "Reject, Repeal and Rectify" but not to witlhold participation. ${ }^{140}$ The practice of medicine under the program, said the resolution, fails to maintain "high ethical regard for all plases of medical care, violates privacy of patient and physician relationship, essentially abolishes patient's selfrespect and personal dignity, nullifies any effort to maintain family responsibility for care and fails to stimulate any honest effort on the part of the patient to carry as much as possible of his financial responsibility ...."147 Participation in the program, however, past and future, did not necessarily indicate approval. If efforts at rejection and repeal failed, the resolution declared the CMA should devote itself to rectification, i.e., to the improvement of the existing program, "recognizing the paramount obligation to protect the welfare of our patients." ${ }^{148}$ The medical care program, according to the resolution, should be returned to the administration and control of the individual counties, "with licensed physicians exercising through their organizations the degree of control over the appropriate agency commensurate with the Physician's responsibility to the patient." 140 In order to speed up the return to local control, the local medical societies were urged to develop and present medical care plans under the program which would have this effect. So far three county medical societies have come forward with such plans. None has yet been approved by the State Social Welfare Bipard as a pilot.

145 SSWB, Verbatim Minutes, July, 1958.

146 California Medical Association House of Delegates, Report of Reference Committee A, April 1958. Quoted in SDSW Circular Letter No. 882 (MC), May 5, 1958.

147 Ibid.

148 Ibid.

149 Ibid. 


\section{APPENDIX}

Table 5

Vendor Payments from Medical Care Fund by Program and Type of Care, April-June 1958*

\begin{tabular}{|c|c|c|c|}
\hline \multirow[b]{2}{*}{ Item } & \multicolumn{3}{|c|}{ Total -3 Aids } \\
\hline & April & May & June \\
\hline Total & $\$ 2,806,751$ & $\$ 2,696,417$ & $\$ 2,296,425$ \\
\hline Physician & 875,300 & 784,513 & 804,269 \\
\hline Other practitioners & 119,063 & 107,211 & 110,320 \\
\hline Prescriptions & $1,445,419$ & $1,474,167$ & $1,064,317$ \\
\hline X-ray & 102,573 & 89,810 & 94,999 \\
\hline Laboratory & 96,865 & 93,127 & 93,158 \\
\hline Home nursing & 42,234 & 31,496 & 28,676 \\
\hline Rehabilitative services & 2,336 & 2,063 & 3,042 \\
\hline Dental care & 110,497 & 106,846 & 84,429 \\
\hline Other & 12,464 & 7,184 & 13,215 \\
\hline
\end{tabular}

Table 6

Cash Grant Payments for Medical Care by Program and Type of Care, April-June 1958

\begin{tabular}{|c|c|c|c|c|c|c|c|c|c|}
\hline \multirow[b]{2}{*}{ Item } & \multicolumn{3}{|c|}{ Total-OAS \& AB } & \multicolumn{3}{|c|}{ Old Age Security } & \multicolumn{3}{|c|}{ Aid to the Blind* } \\
\hline & April & May & June & April & May & June & April & May & June \\
\hline Total... & $\$ 462,630$ & $\$ 449,332$ & $\$ 444,937$ & $\$ 454,913$ & $\$ 442,296$ & $\$ 438,852$ & $\$ 7,717$ & $\$ 7,036$ & $\$ 6,085$ \\
\hline Physician & 349,125 & 342,486 & 341,398 & 343,361 & 337,362 & 336,830 & 5,764 & 5,124 & 4,568 \\
\hline Other practitioners........ & 50,473 & 48,971 & 48,426 & 49,675 & 48,013 & 47,528 & 798 & 958 & 898 \\
\hline 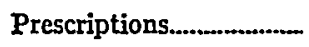 & 395 & 408 & 264 & 386 & 395 & 262 & 9 & 13 & 2 \\
\hline 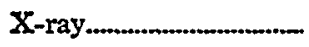 & 19,210 & 18,152 & 18,342 & 18,901 & 17,902 & 18,203 & 309 & 250 & 139 \\
\hline 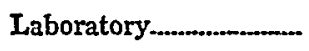 & 32,269 & 29,446 & 26,698 & 31,651 & 28,923 & 26,306 & 618 & 523 & 392 \\
\hline Home nursing.................. & 6,363 & 6,181 & 5,349 & 6,279 & 6,143 & 5,314 & 84 & 38 & 35 \\
\hline Rehabilitative services & 450 & 452 & 496 & 450 & 452 & 484 & $\ldots$ & $\ldots$ & 12 \\
\hline Dental care................. & 1,528 & 922 & 992 & 1,528 & 922 & 984 & $\ldots$ & - & 8 \\
\hline 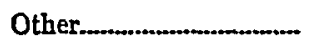 & 2,817 & 2,314 & 2,972 & 2,682 & 2,184 & 2,941 & 135 & 130 & 31 \\
\hline
\end{tabular}

* Includes cash grant payments on behalf of APSB recipients as follows: April. $\$ 22$ 
Analysis of Medical Care Payments Made in February 1958

Table 1. Old Age Security

("Per recipient" averages based on total recipients in caseload.)

\begin{tabular}{|c|c|c|c|}
\hline & Total & $\begin{array}{l}\text { Medical Care } \\
\text { Fund }\end{array}$ & $\begin{array}{l}\text { Cash } \\
\text { Grant }\end{array}$ \\
\hline \multicolumn{4}{|l|}{ All Services } \\
\hline Total cost & $1,215,117$ & $\$ 950,799$ & $\$ 264,318$ \\
\hline Cost per recipient. & 4.58 & & \\
\hline \multicolumn{4}{|l|}{ Prescriptions (Drugs and Other Medical Supplies) } \\
\hline Total cost & 610,838 & 610,425 & 413 \\
\hline Cost per recipient. & 2.30 & & \\
\hline \multicolumn{4}{|l|}{ All Services Except Prescriptions } \\
\hline Total cost & 604,279 & 340,374 & \multirow[t]{2}{*}{263,905} \\
\hline Cost per recipient & 2.28 & & \\
\hline \multicolumn{4}{|l|}{ Physicians } \\
\hline \multicolumn{4}{|l|}{ Visits } \\
\hline Total & 87,460 & & \\
\hline Per 1,000 recipients & 329 & & \\
\hline \multicolumn{4}{|l|}{ Costs } \\
\hline Total & 462,731 & $\$ 248,915$ & \multirow[t]{2}{*}{$\$ 213,81$} \\
\hline Per visit & 5.29 & & \\
\hline Per recipient & 1.74 & & \\
\hline \multicolumn{4}{|l|}{ Other Practitioners } \\
\hline \multicolumn{4}{|l|}{ Visits } \\
\hline Total & 12,684 & & \\
\hline Per 1,000 recipients. & 48 & & \\
\hline \multicolumn{4}{|l|}{ Costs } \\
\hline Total & 54,431 & $\$ 31,473$ & $\$ 22,958$ \\
\hline Per visit & 4.29 & & \\
\hline Per recipient & 0.20 & & \\
\hline \multicolumn{4}{|l|}{ Prescriptions (Drugs and Other Medical Supplies) } \\
\hline Number-Total & 126,598 & & \\
\hline Per 1,000 recipients. & 477 & & \\
\hline Costs-Total ... \$ & 610,838 & $\$ 610,425$ & 413 \\
\hline Per prescription & 4.82 & & \\
\hline 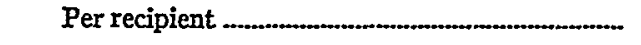 & 2.30 & & \\
\hline \multicolumn{4}{|l|}{ X-Ray } \\
\hline \multicolumn{4}{|l|}{ Costs } \\
\hline Total ................. & 31,820 & 24,426 & 7,394 \\
\hline Per recipient .......... & 0.12 & & \\
\hline \multicolumn{4}{|l|}{ Laboratory } \\
\hline \multicolumn{4}{|l|}{ Costs } \\
\hline Total & 30,819 & 17,164 & 13,655 \\
\hline Per recipient & 0.12 & & \\
\hline \multicolumn{4}{|l|}{ Home Nursing } \\
\hline \multicolumn{4}{|l|}{ Costs } \\
\hline Total .................... & 16,376 & 13,184 & 3,192 \\
\hline Per recipient ... & 0.06 & & \\
\hline
\end{tabular}




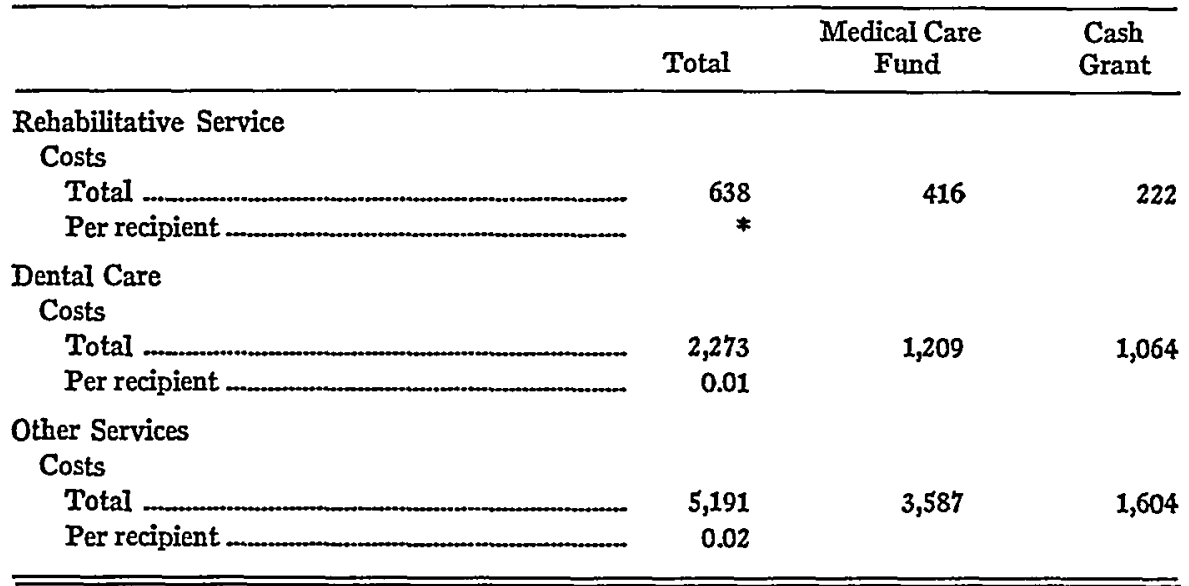

* Less than one cent. 


\section{California Law Review}

MEMBER NATIONAL AND WESTERN CONFERENCES OF TAW REVIEWS

Published Five Times Yearly by Students of the School of Law of the University of Cahifornia, Berkeley, California. Indexed in Index to Legal Periodicals and Public Affairs Information Service.

\section{BOARD OF EDITORS}

\begin{tabular}{|c|c|}
\hline \multicolumn{2}{|c|}{$\begin{array}{c}\text { RICEARD A. WIISON } \\
\text { Editor }\end{array}$} \\
\hline & \\
\hline $\begin{array}{c}\text { GeORGE A. Marroch } \\
\text { Managing Editor }\end{array}$ & $\begin{array}{l}\text { RAIPH J. MOORE, JR. } \\
\text { Article Editor }\end{array}$ \\
\hline \multicolumn{2}{|c|}{$\begin{array}{l}\text { J. WESLEY FRY } \\
\text { Article Editor }\end{array}$} \\
\hline \multicolumn{2}{|c|}{ Associate Editors } \\
\hline ROBERT BURGE & Wriftaar JoHn Martan, Jr. \\
\hline JoHN L. CARDOZA & DAVID E. NIESON \\
\hline EDWIN J. ELDERKIN & H. Michaed PeccorntI \\
\hline Marvin M. Grove & Thomas A. Porter \\
\hline E. Mitus Harvey & NORArAN H. RAIDEN \\
\hline ARTHUR L. HUIMGAX, JR. & SHERWIN L. SAMUUELO \\
\hline K. D. LYDERS & JOHN D. TAYXOR \\
\hline
\end{tabular}

Anse Hosacar

General Secretary

\section{Contributors to This Issue}

JAAIES W. DIIWORTH

FREDERTC L. KTRGIS, JR.

K. D. LYDERS

Davm B. Lyach
George A. Maxioch

Witriakr John Marten, Jr.

RATPH J. Mgore, JR.

David E. Netson

Noraran H. Ramen 